\title{
Durability of Double-Shell Tank Waste Grouts
}

\author{
R. O. Lokken \\ P. F. C. Martin \\ J. W. Shade
}

December 1992

Prepared for the U.S. Department of Energy under Contract DE-AC06-76RLO 1830

Pacific Northwest Laboratory

Operated for the U.S. Department of Energy

by Battelle Memorial Institute

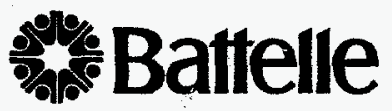




\title{
DISCLAIMER
}

This report was prepared as an account of work sponsored by an agency of the United States Government. Neither the United States Government nor any agency thereof, nor Battelle Memorial Institute, nor any of their employees, makes any warranty, expressed or implied, or assumes any legal liability or responsibility for the accurac $y_{p}$ completeness, or usefulness of any information, apparatus, product, or process disclosed, or represents that its use would not infringe privately owned rights. Reference herein to any specific commercial product, process, or service by trade name, trademark, manufacture, or otherwise does not necessarily constitute or imply its endorsement, recommendation, or favoring by the United States Government or any agency thereof, or Battelle Memorial Institute. The views and opinions of authors expressed herein do not necessarily state or reflect those of the United States Government or any agency thereof.

\author{
PACIFICNORTHWEST LABORATORY \\ operated by \\ BATTELLE MEMORIAL INSTITUTE \\ for the \\ UNITED STATES DEPARTMENT OF ENERGY \\ under Contract DE-ACO6-76RLO 1830
}




\section{DISCLAMMER}

Portions of this document may be illegible in electronic image products. Images are produced from the best available original document. 


\section{DISCLAIMER}

This report was prepared as an account of work sponsored by an agency of the United States Government. Neither the United States Government nor any agency thereof, nor any of their employees, makes any warranty, express or implied, or assumes any legal liability or responsibility for the accuracy, completeness, or usefulness of any information, apparatus, product, or process disclosed, or represents that its use would not infringe privately owned rights. Reference herein to any specific commercial product, process, or service by trade name, trademark, manufacturer, or otherwise does not necessarily constitute or imply its endorsement, recommendation, or favoring by the United States Government or any agency thereof. The views and opinions of authors expressed herein do not necessarily state or reflect those of the United States Government or any agency thereof. 
$-$. 


\section{SUMMARY}

This report summarizes results from studies conducted in FY 1989 to assess the durability of grouted double-shell tank (DST) waste. These studies were performed in support of Westinghouse Hanford Company's Grout Disposal Program to determine the physical and chemical properties of simulated DST grouts cured for extended time periods at elevated temperatures. This report presents results of tests on simulated DST grout samples cured up to 6 months at temperatures ranging from $75^{\circ} \mathrm{C}$ to $95^{\circ} \mathrm{C}$.

A11 the testing and characterization activities were conducted on a single formulation of double-shell slurry feed grout. The simulated waste was the same as that used in the November 1988 pilot-scale test of grout processing characteristics. The dry blend used to prepare the grout consisted of 47 wt\% ground blast furnace slag, 47 wt\% class F fly ash, and 6 wt\% type I/II Portland cement. The dry blend was mixed with the simulated waste at a mix ratio of $91 \mathrm{~b} / g a 1$. The resultant grout slurry was cast into molds and cured at $100 \%$ relative humidity at elevated temperatures $\left(i . e ., 75^{\circ} \mathrm{C}, 85^{\circ} \mathrm{C}\right.$, and $\left.95^{\circ} \mathrm{C}\right)$.

The leach resistance and compressive strength decreased with increased curing times and curing temperatures. The original hydration phases may have densified, resulting in increased pore sizes with corresponding decreases in diffusion path lengths, and therefore, a decrease in leach resistance. The samples absorbed water during curing (up to 9 wt\%) as a result of the osmotic pressures caused by the high salt content within the grout. The osmotic pressure within the grout may have been sufficiently high to cause localized microcracking, thereby reducing strength. Cracking due to increases in internal pressures caused by salt crystallization also may have occurred as the samples cooled from their curing temperatures to room temperature. 


\section{CONTENTS}

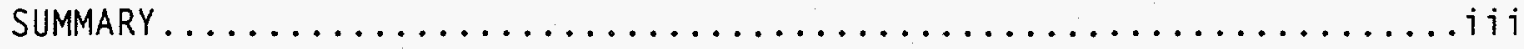

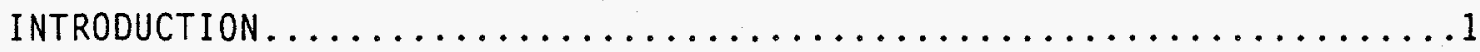

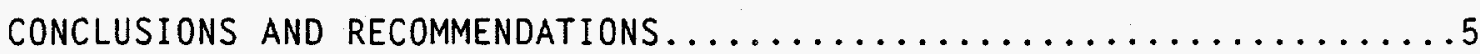

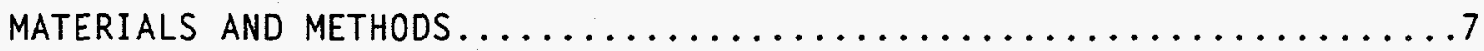

Simulated Waste and Dry Blend.....................

Grout Preparation...............................

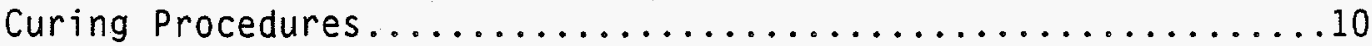

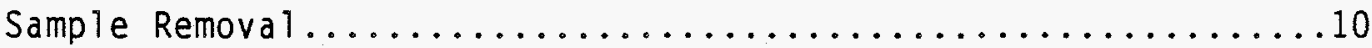

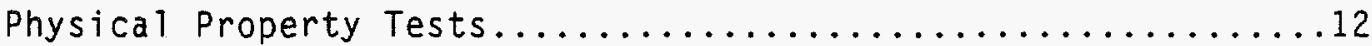

American Nuclear Society (ANS 16.1) Leach Test..............12

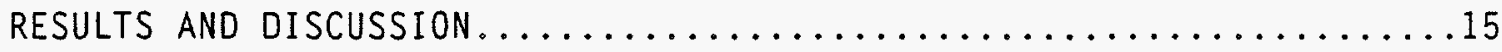

Slurry Properties................................ 15

Weight Change During Curing....................... 15

Compressive Strength. Density, and Moisture Content..........15

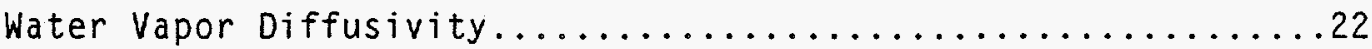

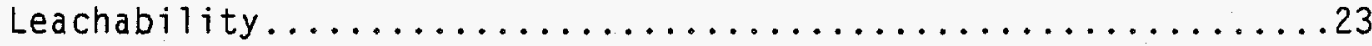

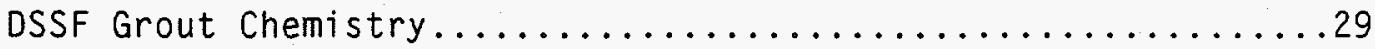

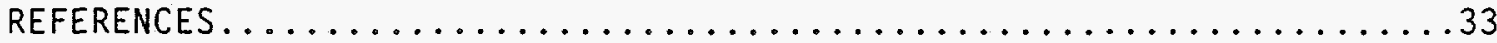




\section{TABLES}

1. Composition of Simulated DSSF Waste Used in These Studies

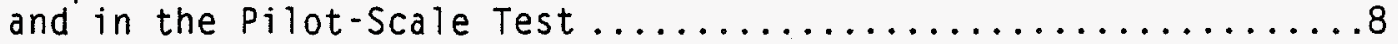

2. Oxide Composition of Blast Furnace Slag. Class F Fly Ash,

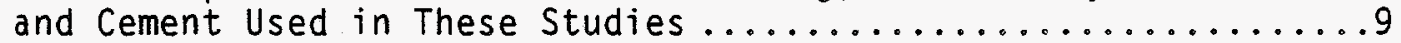

3. Concentration of Trace Metals in Ground Blast Furnace

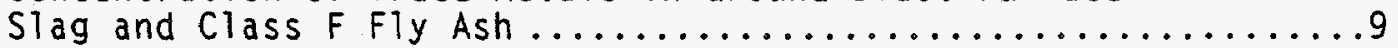

4. Analyzed Composition of Pore Fluid of DSSF Grout after

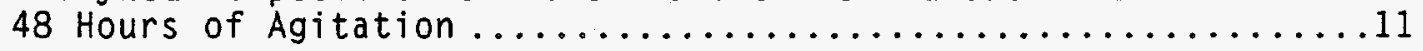

5. Composition of Simulated Pore Solution used for Curing

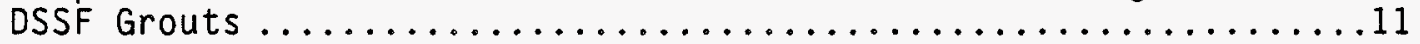

6. Curing Matrix for DSSF Grout Durability Studies ............12

7. Leach Intervals Used for the ANS 16.1 Leach Test ............14

8. Weight Changes for DSSF Grout Samples During Curing for 1 to 6

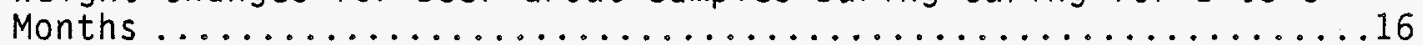

9. Summary of As-Cured Bulk Density and Compressive Strength

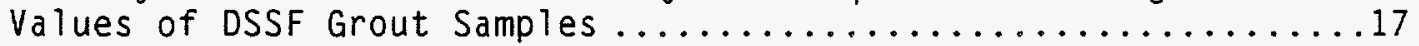

10. Summary of Curing Weight Gain, Evaporable Water Content, and Percentage of Water Reacted During Curing of DSSF Grout Samples.

11. Summary of Corrected Density, Dry Density, and Estimated Volume Change During Curing of DSSF Grout Samples ............20

12. Average Sodium and Nitrate Leachability Indices for DSSF Grout Samples Leached by the ANS 16.1 Procedure .............24

13. Concentration of Solutions Prepared With $2 \mathrm{~g}$ of Dried DSSF Grout

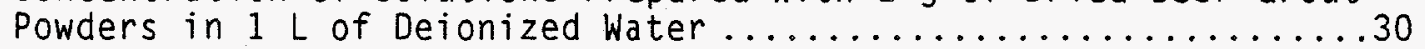

14. Composition of Dried DSSF Grout Powders.....................

15. Pore Solution Concentration for DSSF Grouts Cured at $75^{\circ} \mathrm{C}, 85^{\circ} \mathrm{C}$,

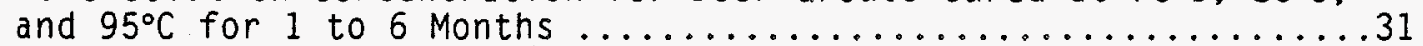




\section{FIGURES}

1. Unconfined Compressive Strength vs. As-Cured Density for DSSF Grout Samples Cured at $75^{\circ} \mathrm{C}, 85^{\circ} \mathrm{C}$, and $95^{\circ} \mathrm{C}$ for 1

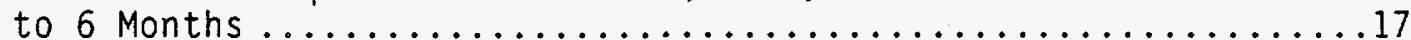

2. Curing Weight Change of DSSF Grouts Cured at $75^{\circ} \mathrm{C}, 85^{\circ} \mathrm{C}$, and $95^{\circ} \mathrm{C}$

3. As-Cured Density as a Function of Weight Change During Curing for DSSF Grout Samples Cured at $75^{\circ} \mathrm{C}, 85^{\circ} \mathrm{C}$, and

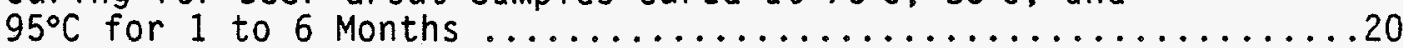

4. As-Cured Density vs. Density Corrected for Curing Weight Change for DSSF Grout Samples Cured at $75^{\circ} \mathrm{C}, 85^{\circ} \mathrm{C}$, and

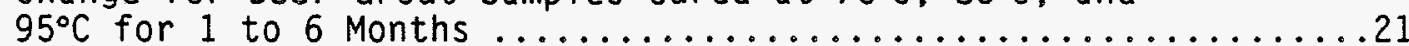

5. Water Vapor Diffusion Out of and Into DSSF Grout Samples at

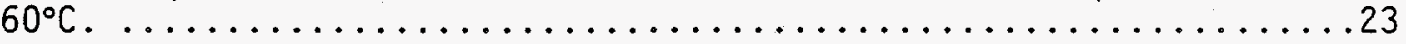

6. Cumulative Fraction Nitrate Leached From DSSF Grout Samples

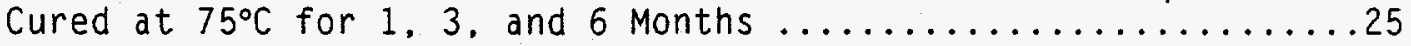

7. Cumulative Fraction Nitrate Leached From DSSF Grout Samples

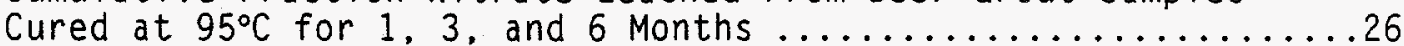

8. Leachate pH from ANS 16.1 Leach Tests on DSSF Grout Samples Cured for 1 Month at $75^{\circ} \mathrm{C}, 85^{\circ} \mathrm{C}$, and $95^{\circ} \mathrm{C}$.

9. Leachate $\mathrm{pH}$ from ANS 16.1 Leach Tests on DSSF Grout Samples Cured for 6 Months at $75^{\circ} \mathrm{C}, 85^{\circ} \mathrm{C}$, and $95^{\circ} \mathrm{C}$.

10. Sodium Leachability Index for DSSF Grouts as a Function

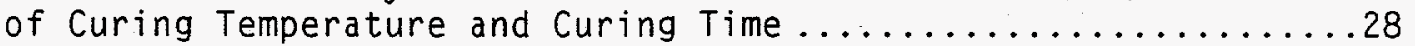

11. Nitrate Leachability Index for DSSF Grouts as a Function of Curing Temperature and Curing Time 


\section{INTRODUCTION}

Current plans at Hanford for disposal of selected low-level liquid wastes include solidification of the wastes using hydraulic binders (i.e., grouting). Grout disposal is intended for double-shell slurry feed (DSSF) waste, one of the types of low-level wastes stored in double-shell tanks on the Hanford Site. The initial formulation for DSSF waste grout included a dry blend consisting of approximately 47 wt\% ground blast furnace slag, 47 wt\% fly ash, and 6 wt\% portland cement. The dry blend is mixed with liquid waste at a nominal ratio of $9 \mathrm{lb}$ of solids per gallon of waste $(1080 \mathrm{~g} / \mathrm{L})$. This formulation was developed to meet specified criteria for processing, leachability, and physical properties of the grouted waste form. Because of time constraints during formulation studies, tests using these grouts were conducted after relatively short curing times at temperatures that do not accurately simulate the temperatures that will occur under the expected disposal conditions. While the grouts prepared with the current formulation met most formulation criteria, additional information is needed to verify that long-term reactions within the grout at elevated temperatures will not sacrifice integrity of the disposal system and result in less favorable performance.

The majority of conventional concretes and mortars used in the construction industry are produced with Portland cement. The hydration reactions, hydration products, and deterioration mechanisms of such systems have been studied extensively (e.g., Lea 1971 and Neville 1981). Many studies have been conducted using accelerated testing methods to estimate the service lives of conventional concrete structures. Most of these studies did not provide reliable predictors of durability, primarily because of the numerous interactions between deterioration mechanisms and difficulties in reliably controlling the test conditions.

DSSF grouts are unique in their composition and their intended purpose. The hydration reactions for DSSF grout are expected to be quite different from those for conventional concretes (Lea 1971, Regourd et al. 1983, wu et al. 1983). Other complicating factors include the high salt content in the waste and high curing temperatures. High-temperature curing and the presence of 
salts affect the rates of reactions and influence the microstructure, composition, and physical properties of the reaction products.

The long-term durability requirements and degradation mechanisms of DSSF grouts differ from those for conventional concrete structures. Deterioration of concrete is most often caused by cyclic environmental conditions (e.g.. freeze/thaw cycles, wet/dry cycles) and/or external chemical interactions (e.g.. deicing salts, acid rain. carbonation, etc.). DSSF grouts will not be exposed to such conditions. At the planned disposal depths, annual freeze/thaw cycles will not occur. By design of the disposal system (i.e., through the use of a diffusion barrier), the grout will not be exposed to external chemical influences. Other factors may affect the durability of the grouts, however. These factors include high temperatures $\left(\sim 90^{\circ} \mathrm{C}\right)$, temperature gradients, moisture gradients, composition gradients, internal chemical reactions, and radiation. Under the expected disposal conditions, the temperature of the grout will peak twice. The first peak will result from hydration heat, and the second will result from radioactive decay heat. The grouts will remain at elevated temperatures for many years. The high temperatures expected during the first few decades after disposal will increase the driving force for water vapor transport away from the grouts; the loss of water may result in cracking, dehydration of hydrated phases, and precipitation of salts from saturated pore solution. As the grout cools, the osmotic pressure caused by the high salt content may draw moisture back into the grout mass. The uptake of moisture may have detrimental impacts on the behavior of the grout.

In addition, the initial curing conditions during the first few months after production are expected to greatly influence the long-term properties of the grout. Curing temperatures will vary with position within the grout because of the time required to fill the vault. the temperature gradient due to hydration heat, and heat loss to the surroundings. The differences in temperature may also result in moisture gradients and concentration gradients of salts in solution.

The objective of the study reported here was to qualitatively assess the long-term durability of DSSF grouts (i.e., to determine whether any changes 
could occur in grout properties that would significantly affect performance). DSSF grouts were subjected to a range of curing conditions and were then tested to identify chemical and physical reactions in the grout that could possibly impact the performance of the disposal system. This report presents results of tests on simulated DSSF grout samples cured up to 6 months at temperatures ranging from $75^{\circ} \mathrm{C}$ To $95^{\circ} \mathrm{C}$. 



\section{CONCLUSIONS AND RECOMMENDATIONS}

Samples of laboratory-produced DSSF grout that were cured at temperatures of $75^{\circ} \mathrm{C}, 85^{\circ} \mathrm{C}$, and $95^{\circ} \mathrm{C}$ for up to 6 months have been tested and characterized to determine the relative changes in grout properties. Based on the test results, the following observations can be made:

- The leach resistance and compressive strength of most of the DSSF grout samples decreased with increased curing time and increased curing temperature

- The bulk volume of the DSSF grout samples did not change appreciably during curing

- DSSF grout samples absorbed water during curing at temperatures up to $95^{\circ} \mathrm{C}$.

The decreased compressive strengths and leach resistance of the grouts may be due to densification of hydrated phases and/or to microcracking caused by high internal pressures resulting from water absorption or salt crystallization. Additional testing and characterization will address the following questions:

- Why do longer curing times and higher curing temperatures (up to $95^{\circ} \mathrm{C}$ ) result in decreases in leach resistance and compressive strengths?

- What are the impacts of changing the formulation of DSSF grouts (e.g., diluting the dry blend to reduce total heat generation) on the physical and chemical properties of the grout?

- Does the development of additional crystalline phases change the overall leachability of DSSF grouts? Does temperature accelerate reactions to the point where grouts cured at low temperature and long times yield the same phases as short-term curing at higher temperature?

- Can the new phases be predicted by chemical speciation/solubility calculations of pore fluid and/or leach solution composition? Are the phases in equilibrium with the fluids? 
The following activities are currently underway to answer these questions:

- Statistically designed experiments are being used to identify and quantify the effects of dry blend composition, curing conditions, and waste composition.

- Curing conditions are being more stringently controlled to control weight changes during curing and to provide more accurate mass balances (i.e., moisture gain in samples cured up to $95^{\circ} \mathrm{C}$ ).

- Detailed microstructural characterization is being made to determine the extent. if any, of microcracks or gross microstructural changes that may affect leaching and strength.

- Pore size distribution measurements are being conducted to correlate physical and chemical changes that occur within the grout. 


\section{MATERIALS AND METHODS}

\section{SIMULATED WASTE AND DRY BLEND}

The simulated DSSF liquid waste used in these studies was obtained from a large batch prepared for use in the November 1988 pilot-scale test of grout processing characteristics (Whyatt 1989(a) and Lokken et a 1. 1992). The nominal and analyzed composition of the simulated waste is listed in Table 1.

The reference dry blend composition, composed of 47 wt\% blast furnace slag obtained from Ash Grove Cement West, 47 wt\% class F fly ash from Centralia. Washington, and 6 wt\% type I/II Portiand cement from Ash Grove Cement West, was used in this study. The dry materials were mixed in a $V$ blender for 23 hours prior to grout preparation. Four $10-\mathrm{kg}$ batches were prepared in this manner. The oxide composition of the major constituents in the individual dry materials, as determined by inductively coupled plasma (ICP) spectroscopy, is listed in Table 2. Table 3 lists the concentrations of trace metals in the materials as determined by $X$-ray fluorescence (XRF) analysis.

\section{GROUT PREPARATION}

Grouts were prepared using a Hobart mixer and a wire whip. The waste was preheated to approximately $45^{\circ} \mathrm{C}$, and then $2 \mathrm{~L}$ were poured into the mixer bow 1. Room temperature dry blend was added to the waste at a mix ratio of $9 \mathrm{lb} / \mathrm{gal}$ $(1.08 \mathrm{~kg} / \mathrm{L})$. After mixing, the grout slurry was poured into an insulated container and the slurry was continuously agitated. Five batches of grout slurry were prepared in this manner. Samples of DSSF grout slurry were cast into preweighed, polypropylene jars of either $75-\mathrm{mL}$ or $35-\mathrm{mL}$ capacity. The jars were then capped, weighed, and placed in vessels for curing as described below. A total of 239 grout samples were prepared. Grout slurry samples from the first batch and the last batch were tested for density and for rheology using a Fann viscometer.

(a) Whyatt, G. A. 1989. Pilot-Scale Production of Grout with Simulated Double-Shell Slurry Feed. PNL-draft, Pacific Northwest Laboratory. Richland. Washington. 
IABLE 1. Composition of Simulated DSSF Waste

\begin{tabular}{|c|c|c|}
\hline \multirow[b]{2}{*}{ Species } & \multicolumn{2}{|c|}{ Composition, g/L } \\
\hline & Analyzed(a) & Nominal (b) \\
\hline A1 & 22.4 & 20.3 \\
\hline B & 0.136 & 0.105 \\
\hline $\mathrm{Ba}$ & 0.6 & 0.623 \\
\hline $\mathrm{Ca}$ & 0.573 & 0.2 \\
\hline $\mathrm{Cr}$ & 1.26 & 1.15 \\
\hline $\mathrm{Fe}$ & 1.49 & 1.41 \\
\hline$k$ & 11.5 & 9.72 \\
\hline $\mathrm{Mg}$ & 0.32 & \\
\hline Mn & 3.01 & 2.75 \\
\hline Mo & 0.068 & 0.049 \\
\hline $\mathrm{Na}$ & 122 & 121.8 \\
\hline $\mathrm{Si}$ & 0.502 & 0.56 \\
\hline $2 n$ & 2.93 & 1.63 \\
\hline $\mathrm{Cl}^{-}$ & 5.36 & 3.86 \\
\hline $\mathrm{NO}_{2}^{-}$ & 27.2 & 23.0 \\
\hline $\mathrm{PO}_{4}^{-3}$ & 5.4 & 5.65 \\
\hline $\mathrm{NO}_{3}^{-}$ & 186 & 154.4 \\
\hline $\mathrm{SO}_{4}^{-2}$ & 5.1 & 5.05 \\
\hline $\operatorname{TOC}(\mathrm{C})$ & 1.556 & 1.28 \\
\hline
\end{tabular}

(a) Analyzed for this study

(b) Claghorn (1987)

(c) Total organic carbon as EDTA and citrate 
TABLE 2. Oxide Composition of Blast Furnace Slag. Class F Fly Ash, and Cement

\begin{tabular}{|c|c|c|c|}
\hline \multirow[b]{2}{*}{ Oxide } & \multicolumn{3}{|c|}{ Composition, wt\%(a) } \\
\hline & Slag & Fly Ash & Cement \\
\hline $\mathrm{Al}_{2} \mathrm{O}_{3}$ & 13.4 & 23.5 & 3.3 \\
\hline $\mathrm{B}_{2} \mathrm{O}_{3}$ & & 0.5 & 0.105 \\
\hline $\mathrm{BaO}$ & 0.117 & 0.169 & 0.084 \\
\hline $\mathrm{CaO}$ & 43.4 & 8.05 & 65.4 \\
\hline $\mathrm{Fe}_{2} \mathrm{O}_{3}$ & 0.377 & 5.73 & 4.08 \\
\hline $\mathrm{K}_{2} \mathrm{O}$ & 0.89 & 0.98 & 0.65 \\
\hline $\mathrm{MgO}$ & 5.62 & 1.57 & 1.38 \\
\hline $\mathrm{MnO}_{2}$ & 1.03 & 0.088 & 0.072 \\
\hline $\mathrm{Na}_{2} \mathrm{O}$ & 0.401 & 3.02 & 0.32 \\
\hline $\mathrm{P}_{2} \mathrm{O}_{5}$ & & 0.94 & \\
\hline $\mathrm{SiO}_{2}$ & 33.3 & 47.8 & 22.2 \\
\hline Sro & 0.078 & 0.31 & 0.035 \\
\hline $\mathrm{TiO}_{2}$ & 1.08 & 4.43 & 0.22 \\
\hline Total & 99.693 & 97.087 & 97.846 \\
\hline
\end{tabular}

(a) Determined by ICP analysis

IABLE 3. Concentration of Trace Metals in Ground Blast Furnace Slag and Class F Fly Ash

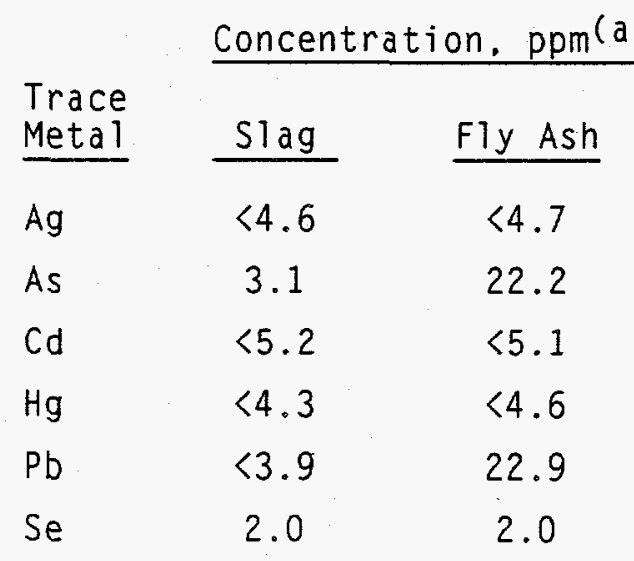

(a) Determined by XRF analysis 


\section{CURING PROCEDURES}

The polypropylene jars containing the grout slurry were placed in vessels containing a solution approximating the composition of the initial pore solution in the grout. The composition of the pore solution was determined by preparing DSSF grout slurry in the standard manner, agitating the slurry for approximately 48 hours at room temperature, filtering the slurry, and analyzing the filtrate. The filtrate was analyzed by ICP, ion chromatography (IC), and acid titration for hydroxide content. Table 4 list the results of these analyses. Based on these results, a simulated pore solution was prepared that contained the major constituents identified by the analyses. Table 5 lists the amounts of compounds used to prepare the simulated pore solution.

Curing the grout samples in the simulated pore solution minimized osmotic pressure gradients through the polypropylene jars and maintained constant moisture conditions, thereby minimizing the transport of water into or out of the grout by decreasing the driving force for water vapor transport.

The vessels containing the grout samples (inside the polypropylene jars) and the simulated pore fluid were $\mathrm{placed}$ in ovens initially operating at $25^{\circ} \mathrm{C}$ to $35^{\circ} \mathrm{C}$. The temperature of the ovens was increased over a 3 -day period to $95^{\circ} \mathrm{C}, 85^{\circ} \mathrm{C}$, or $75^{\circ} \mathrm{C}$. Table 6 lists the number of samples cured at each temperature.

\section{SAMPLE REMOVAL}

After curing for the desired time periods, the samples were removed from the vessels and were placed into other vessels containing the simulated pore solution that had been preheated to the appropriate curing temperature. The samples in these vessels were allowed to cool slowly to room temperature. The grout samples were removed from the polypropylene jars by carefully cutting one side of the jar with the tip of a hot soldering iron. Upon removal, the grout specimens were weighed and then stored in plastic bags until tested. 
IABLE 4. Analyzed Composition of Pore Fluid of DSSF Grout After 48 Hours of Agitation

\begin{tabular}{lcc} 
Species & & $\begin{array}{c}\text { Composition, } \\
\mathrm{g} / \mathrm{L}\end{array}$ \\
\cline { 1 - 1 } $\mathrm{Al}$ & & 1.04 \\
$\mathrm{~B}$ & & 0.36 \\
$\mathrm{Ca}$ & & 0.41 \\
$\mathrm{Cr}$ & & 0.82 \\
$\mathrm{~K}$ & & 12.5 \\
$\mathrm{Na}$ & & 157 \\
$\mathrm{Si}$ & & 1.25 \\
$\mathrm{OH}^{-}$ & & $1.60 \mathrm{M}$ \\
$\mathrm{Cl}^{-}$ & & 3.2 \\
$\mathrm{NO}_{2}^{-}$ & & 30 \\
$\mathrm{NO}_{3}^{-}$ & & 200 \\
$\mathrm{PO}_{4}{ }^{3-}$ & 1.3 \\
$\mathrm{SO}_{4}{ }^{-}$ & 20
\end{tabular}

IABLE 5. Composition of Simulated Pore Solution Used for Curing DSSF Grouts

\begin{tabular}{|c|c|}
\hline Compound & $\begin{array}{c}\text { Amount, } \\
\mathrm{m} / \mathrm{L}\end{array}$ \\
\hline $\mathrm{HNO}_{3}$ & 2.91 \\
\hline $\mathrm{Na}_{2} \mathrm{CO}_{3}$ & 0.538 \\
\hline $\mathrm{NaCl}$ & 0.09 \\
\hline $\mathrm{KNO}_{3}$ & 0.32 \\
\hline $\mathrm{NaAlO}_{2}$ & 0.0385 \\
\hline $\mathrm{NaOH}$ & 4.51 \\
\hline $\mathrm{Na}_{2} \mathrm{SO}_{4}$ & 0.21 \\
\hline $\mathrm{NaNO}_{2}$ & 0.65 \\
\hline
\end{tabular}


TABLE 6. Curing Matrix for DSSF Grout Durability Studies

\begin{tabular}{|c|c|c|c|}
\hline \multirow[b]{2}{*}{$\begin{array}{l}\text { Curing } \\
\text { Time } \\
\end{array}$} & \multicolumn{3}{|c|}{$\begin{array}{c}\text { Number of Samples Cured } \\
\text { at Each Temperature } \\
\end{array}$} \\
\hline & $95^{\circ} \mathrm{C}$ & $85^{\circ} \mathrm{C}$ & $75^{\circ} \mathrm{C}$ \\
\hline 28 days & 9 & 9 & 9 \\
\hline 2 month & 5 & 5 & 5 \\
\hline 3 months & 11 & 9 & 11 \\
\hline 4 months & 5 & 5 & 5 \\
\hline 6 months & 10 & 10 & 10 \\
\hline$>6$ months $(a)$ & 20 & 20 & 20 \\
\hline
\end{tabular}

(a) Additional samples produced and cured for long-term evaluation

\section{PHYSICAL PROPERTY TESTS}

Compressive strength testing was conducted with an Instron(a) test machine at a constant crosshead speed of $0.05 \mathrm{in.} / \mathrm{min}$. The load-to-failure was determined from the maximum point of a load-deformation curve. Compressive strength values were calculated by dividing the maximum load by the cross-sectional surface area of the cylinders. The length-to-diameter ratio of these samples was one. Bulk density was determined by dividing the weight of the compressive strength samples by their bulk volume as determined by length and diameter measurements.

The moisture content, or amount of evaporable water, of the grouts was determined by drying the compressive strength samples (after testing) to a constant weight at $105^{\circ} \mathrm{C} \pm 2^{\circ} \mathrm{C}$.

\section{AMERICAN NUCLEAR SOCIETY (ANS 16.1) LEACH TEST}

The ANS 16.1 leach test (ANS 1986) was used to determine the effects of curing temperature and curing time on leachability. The test is an intermittent leachate exchange test designed to simulate a dynamic leaching

(a) Instron Corporation, Canton, Massachusetts 
situation. The leachate exchange intervals used for these tests are listed in Table 7.

The samples used in these tests were cylindrical, with approximate dimensions of $3.2-\mathrm{cm}$ dia. by $4.5 \mathrm{~cm}$ high. The samples, with a nominal surface area of $61 \mathrm{~cm}^{2}$, were suspended by nylon monofilament in approximately $610 \mathrm{~mL}$ of deionized water within polyethylene containers. The ANS leach tests were conducted through 91 days. After the elapsed time periods, the samples were removed from the leachates and placed into containers containing fresh leachant. The pH of the leachates was measured immediately after removing the samples. Aliquots of leachate were filtered through a $0.45 \mu \mathrm{m}$ filter and then submitted for cation analysis by ICP, for anion analysis by $I C$, and for analysis of total organic carbon (TOC).

The ANS 16.1 leach test was used in these studies to determine the relative leaching resistance for major cations and anions and to determine changes in leachability due to different curing conditions. Also, changes in the leaching behavior can provide some insight into physical and chemical changes that may be occurring in the grout. The ANS 16.1 leach test is designed to determine a "figure of merit" parameter called the leachability index $(L)$. The leachability index for a given species is defined as the negative logarithm (base 10) of the effective diffusion coefficient (D) of that species. When less than $20 \%$ of a given species is leached, the effective diffusivity is given by (ANS 1986):

$$
D=\pi\left[\frac{\left(a_{n} / A_{0}\right)}{(\Delta t)_{n}}\right]^{2}\left[\frac{V}{S}\right]^{2} T
$$

where $\quad D=$ effective diffusivity, $\mathrm{cm}^{2} / \mathrm{s}$

$a_{n}=$ concentration of ion released from the specimen during the leaching interval $n$

$A_{0}=$ total amount of species in the specimen at the beginning of the leach test

$(\Delta t)_{n}=t_{n}-t_{n-1}$, duration of the $n$-th leaching interval, s

$V=$ volume of specimen, $\mathrm{cm}^{3}$

$\mathrm{S}=$ geometric surface area of specimen, $\mathrm{cm}^{2}$

$T=\left[1 / 2\left(\sqrt{t_{n}}+\sqrt{t_{n-1}}\right)\right]^{2}$, representing the "mean time" of the leaching interval, s. 
When greater than $20 \%$ of the total inventory of a species is leached, the effective diffusivity is calculated by:

$$
D=\frac{G d^{2}}{t}
$$

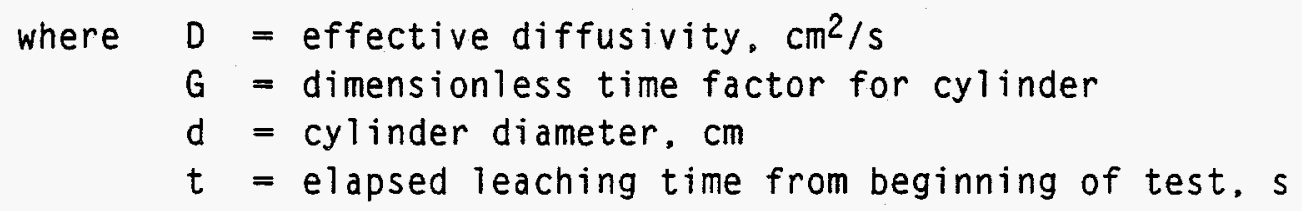

IABLE 7. Leach Intervals Used for the ANS 16.1 Leach Test

\begin{tabular}{|c|c|c|}
\hline $\begin{array}{c}\text { Leach } \\
\text { Interval } \\
\text { No. } \\
\end{array}$ & $\begin{array}{c}\text { Time } \\
\text { Between } \\
\text { Intervals } \\
\end{array}$ & $\begin{array}{c}\text { Cumulative } \\
\text { Time }\end{array}$ \\
\hline 1 & $7 \mathrm{hr}$ & $7 \mathrm{hr}$ \\
\hline 2 & $17 \mathrm{hr}$ & $1 \mathrm{~d}$ \\
\hline 3 & $24 \mathrm{hr}$ & $2 d$ \\
\hline 4 & $48 \mathrm{hr}$ & $4 d$ \\
\hline 5 & $72 \mathrm{hr}$ & $7 d$ \\
\hline 6 & $7 d$ & $14 \mathrm{~d}$ \\
\hline 7 & $14 d$ & $28 d$ \\
\hline 8 & $28 d$ & $56 \mathrm{~d}$ \\
\hline 9 & $35 d$ & $91 d$ \\
\hline
\end{tabular}




\section{RESULTS AND DISCUSSION}

This section presents the results obtained to date on properties of DSSF grouts prepared for studying the long-term behavior of the grout at elevated curing temperatures.

\section{SLURRY PROPERTIES}

Two samples of DSSF grout slurry were collected during the sample casting procedure for use in determining slurry density and rheological properties. The densities of the slurries were 1.65 and $1.66 \mathrm{~g} / \mathrm{cm}^{3}$ and the critical flow rates were 36.1 and $38.1 \mathrm{gpm}$, respectively, for the samples collected at the beginning and at the end of the casting period. The measured densities were within the range of densities measured on other DSSF grout samples prepared with the same waste and dry blend. The average density of these grout slurries was $1.66 \mathrm{~g} / \mathrm{cm}^{3}$, with a standard deviation of $0.01 \mathrm{~g} / \mathrm{cm}^{3}$. The critical flow rates were below the maximum acceptable limit of $60 \mathrm{gpm}$.

\section{WEIGHT CHANGE DURING CURING}

The DSSF grout samples were cured in sealed polypropylene jars placed in secondary vessels that contained a simulated pore solution. As discussed previously, these conditions were intended to minimize water vapor transport into or out of the grouts. However. the majority of the grout samples gained weight during curing. Table 8 lists the average weight changes for the DSSF grout samples cured up to 6 months. Further discussion on the weight changes during curing for the compressive strength samples and the effects on other properties is presented in the following section.

\section{COMPRESSIVE STRENGTH. DENSITY, AND MOISTURE CONTENT}

Table 9 summarizes the results of unconfined compressive strength and ascured bulk density measurements. As a general rule, the average compressive strength decreased as the bulk density of the samples increased. This effect is illustrated in Figure 1 , which shows data from samples cured at $75^{\circ} \mathrm{C}, 85^{\circ} \mathrm{C}$ and $95^{\circ} \mathrm{C}$ for 1 to 6 months. Although there is considerable scatter in the 
TABLE 8. Weight Changes for DSSF Grout Samples During Curing for 1 to 6 Months

\begin{tabular}{|c|c|c|c|c|c|}
\hline Curing & Average Weight & & Rang & $w t \%$ & No. of \\
\hline Temp.. ${ }^{\circ} \mathrm{C}$ & Change, wt\% & S.0.(a) & Low & $\mathrm{High}$ & Samples \\
\hline 75 & 2.90 & 2.78 & -0.64 & 9.06 & 39 \\
\hline 85 & 4.50 & 2.48 & -4.03 & 9.00 & 37 \\
\hline 95 & 6.57 & 2.20 & 0.43 & 9.78 & 38 \\
\hline
\end{tabular}

(a) S.D. = One standard deviation from average

data around the regression line, the correlation is still relatively good $\left(R^{2}\right.$ $=0.76$ ) considering the range of curing times and curing temperatures of the samples. The decrease in compressive strength with increasing density (or weight gain) could have been caused by high internal pressures exerted within the grout structure by the imbibed water, thus resulting in the formation of microcracks. Microcracking also may have occurred as the grout samples cooled from their respective curing temperatures to room temperature. Because the solubility of the salts likely would be higher at the elevated temperatures, decreasing the temperature could have resulted in the crystallization of salts, with corresponding increases in internal pressures associated with crystallization.

Following compressive strength testing. the samples were dried to constant weight at $105^{\circ} \mathrm{C}$ to determine the amount of evaporable water present within the samples. The weight change during curing, evaporable water content, and amount of bound water in the DSSF grout samples are summarized in Table 10. The amount of bound, or reacted, water in the samples was calculated assuming the initial water content was $37.2 \mathrm{wt} \%$, the initial density was $1.66 \mathrm{~g} / \mathrm{cm}^{3}$. all weight change during curing was due to the gain or loss of water, and a 11 weight lost during drying at $105^{\circ} \mathrm{C}$ was from water loss. 
TABLE 9. Summary of As-Cured Bulk Density and Compressive Strength Values of DSSF Grout Samples

\begin{tabular}{|c|c|c|c|c|c|}
\hline $\begin{array}{l}\text { Curing } \\
\text { Temp. . }{ }^{\circ} \mathrm{C}\end{array}$ & $\begin{array}{l}\text { Curing } \\
\text { Time(a) } \\
\end{array}$ & $\begin{array}{c}\text { Density, } \\
\mathrm{g} / \mathrm{cm}^{3}\end{array}$ & $\begin{array}{r}\text { Compr } \\
\text { Streng } \\
\end{array}$ & $\begin{array}{l}\text { ssive } \\
h, p s i\end{array}$ & $\begin{array}{l}\text { No. of } \\
\text { Samples }\end{array}$ \\
\hline 75 & $\begin{array}{l}1 \\
2 \\
3 \\
4 \\
6\end{array}$ & $\begin{array}{l}1.67 \pm 0.01(b) \\
1.70 \pm 0.03 \\
1.70 \pm 0.02 \\
1.77 \pm 0.01 \\
1.75 \pm 0.04\end{array}$ & $\begin{array}{r}1150 \\
1170 \\
1460 \\
730 \\
950\end{array}$ & $\begin{array}{lr} \pm & 30 \\
\pm & 180 \\
\pm & 60 \\
\pm & 230 \\
\pm & 490\end{array}$ & $\begin{array}{l}3 \\
3 \\
2 \\
3 \\
3\end{array}$ \\
\hline 85 & $\begin{array}{l}1 \\
2 \\
3 \\
4 \\
6\end{array}$ & $\begin{array}{l}1.69 \pm 0.02 \\
1.73 \pm 0.03 \\
1.75 \pm 0.06 \\
1.81 \pm 0.01 \\
1.77 \pm 0.06\end{array}$ & $\begin{array}{r}1290 \\
1400 \\
910 \\
500 \\
670\end{array}$ & $\begin{array}{l} \pm 350 \\
\pm 210 \\
\pm 570 \\
\pm \quad 70 \\
\pm \quad 350\end{array}$ & $\begin{array}{l}3 \\
3 \\
3 \\
3 \\
3\end{array}$ \\
\hline 95 & $\begin{array}{l}1 \\
2 \\
3 \\
4 \\
6\end{array}$ & $\begin{array}{l}1.76 \pm 0.04 \\
1.78 \pm 0.03 \\
1.78 \pm 0.01 \\
1.80 \pm 0.00 \\
1.81 \pm 0.00\end{array}$ & $\begin{array}{r}1020 \\
610 \\
540 \\
410 \\
330\end{array}$ & $\begin{array}{rr} \pm & 180 \\
\pm & 220 \\
\pm & 160 \\
\pm & 20 \\
\pm & 0\end{array}$ & $\begin{array}{l}2 \\
2 \\
3 \\
3 \\
2\end{array}$ \\
\hline
\end{tabular}

(a) Curing time in months

(b) \pm values represent one standard deviation from average

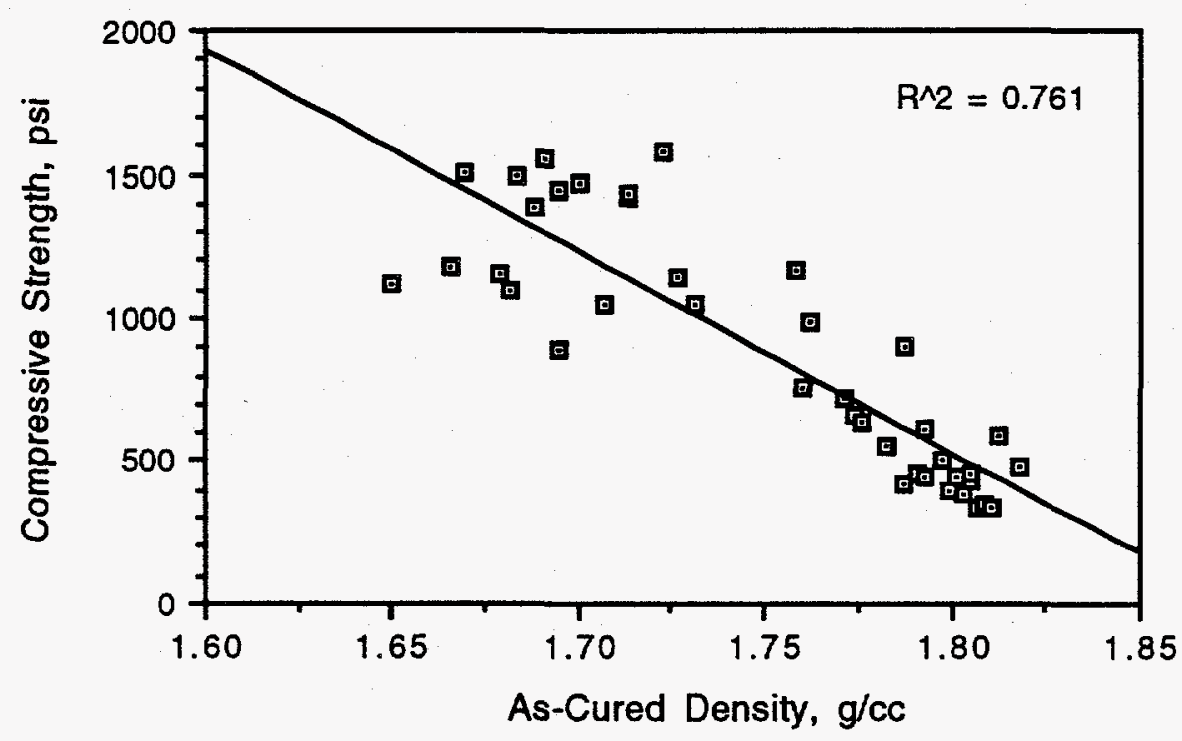

FIGURE 1. Unconfined Compressive Strength vS. As-Cured Density for DSSF Grout Samples Cured at $75^{\circ} \mathrm{C}, 85^{\circ} \mathrm{C}$, and $95^{\circ} \mathrm{C}$ for 1 to 6 Months 
IABLE 10. Summary of Curing Weight Gain. Evaporable Water Content, and Percentage of Water Reacted During Curing of DSSF Grout Samples

\begin{tabular}{|c|c|c|c|c|c|c|c|c|c|c|c|}
\hline \multirow{2}{*}{$\begin{array}{l}\text { Curing } \\
\text { Temp.. }^{\circ} \mathrm{C}\end{array}$} & \multirow{2}{*}{$\begin{array}{c}\text { Curing } \\
\text { Time(a) } \\
1 \\
2 \\
3 \\
4 \\
6\end{array}$} & \multicolumn{3}{|c|}{$\begin{array}{c}\text { Weight Change } \\
\text { During Curing, } \\
\text { wt\%(b) }\end{array}$} & \multicolumn{3}{|c|}{$\begin{array}{c}\text { Evaporable } \\
\text { Water Content, } \\
\text { wt\%(c) }\end{array}$} & \multicolumn{3}{|c|}{$\begin{array}{c}\text { Water Reacted, } \\
\text { wt\%(d) }\end{array}$} & \multirow{2}{*}{$\begin{array}{c}\text { No. of } \\
\text { Samples } \\
3 \\
3 \\
2 \\
3 \\
3\end{array}$} \\
\hline & & $\begin{array}{l}0.12 \\
2.08 \\
2.55 \\
6.82 \\
5.37\end{array}$ & $\begin{array}{l} \pm \\
\pm \\
\pm \\
\pm \\
\pm\end{array}$ & $\begin{array}{l}0.56^{(\mathrm{e})} \\
1.49 \\
1.08 \\
1.21 \\
3.27\end{array}$ & $\begin{array}{l}32.3 \\
31.2 \\
30.8 \\
29.8 \\
30.4\end{array}$ & $\begin{array}{l} \pm \\
\pm \\
\pm \\
\pm \\
\pm\end{array}$ & $\begin{array}{l}0.4 \\
1.0 \\
0.7 \\
0.5 \\
0.9\end{array}$ & $\begin{array}{l}13.3 \\
18.9 \\
20.5 \\
27.7 \\
24.6\end{array}$ & $\begin{array}{l} \pm \\
\pm \\
\pm \\
\pm \\
\pm\end{array}$ & $\begin{array}{l}1.7 \\
4.5 \\
3.2 \\
1.8 \\
5.5\end{array}$ & \\
\hline 85 & $\begin{array}{l}1 \\
2 \\
3 \\
4 \\
6\end{array}$ & $\begin{array}{l}2.64 \\
4.33 \\
5.61 \\
8.77 \\
5.60\end{array}$ & $\begin{array}{l} \pm \\
\pm \\
\pm \\
\pm \\
\pm\end{array}$ & $\begin{array}{l}1.13 \\
2.35 \\
4.37 \\
0.35 \\
3.75\end{array}$ & $\begin{array}{l}31.2 \\
30.3 \\
29.8 \\
28.7 \\
30.1\end{array}$ & $\begin{array}{l} \pm \\
\pm \\
\pm \\
\pm \\
\pm\end{array}$ & $\begin{array}{l}0.8 \\
1.4 \\
1.2 \\
1.1 \\
1.0\end{array}$ & $\begin{array}{l}19.6 \\
23.7 \\
26.0 \\
32.0 \\
25.4\end{array}$ & $\begin{array}{l} \pm \\
\pm \\
\pm \\
\pm \\
\pm\end{array}$ & $\begin{array}{l}3.4 \\
6.0 \\
7.8 \\
2.8 \\
6.0\end{array}$ & $\begin{array}{l}3 \\
3 \\
3 \\
3 \\
3\end{array}$ \\
\hline 95 & $\begin{array}{l}1 \\
2 \\
3 \\
4 \\
6\end{array}$ & $\begin{array}{l}5.74 \\
6.57 \\
6.71 \\
8.44 \\
9.58\end{array}$ & $\begin{array}{l} \pm \\
\pm \\
\pm \\
\pm \\
\pm\end{array}$ & $\begin{array}{l}1.90 \\
1.85 \\
0.53 \\
0.72 \\
0.29\end{array}$ & $\begin{array}{l}29.8 \\
30.3 \\
29.8 \\
30.2 \\
30.1\end{array}$ & $\begin{array}{l} \pm \\
\pm \\
\pm \\
\pm \\
\pm\end{array}$ & $\begin{array}{l}2.3 \\
1.4 \\
0.9 \\
0.3 \\
0.1\end{array}$ & $\begin{array}{l}26.4 \\
26.1 \\
27.7 \\
28.3 \\
29.4\end{array}$ & $\begin{array}{l} \pm \\
\pm \\
\pm \\
\pm \\
\pm\end{array}$ & $\begin{array}{l}7.7 \\
5.4 \\
.1 .6 \\
1.4 \\
0.0\end{array}$ & $\begin{array}{l}2 \\
2 \\
3 \\
3 \\
2\end{array}$ \\
\hline
\end{tabular}

(a) Curing time in months

(b) Calculated by [(As-cured Wt - Initial Wt) / Initial Wt * 100\%]

(c) Calculated by [(Wet Wt - Dry Wt) / Wet Wt * 100\%]

(d) Calculated by [(Total $\mathrm{H}_{2} \mathrm{O}$ - Evap. $\mathrm{H}_{2} \mathrm{O}$ ) / Total $\mathrm{H}_{2} \mathrm{O} * 100 \%$ ]

(e) \pm values represent one standard deviation from average

Figure 2 illustrates the effect of curing time and curing temperature on the weight changes. The average weight of DSSF grout samples cured at $75^{\circ} \mathrm{C}$, $85^{\circ} \mathrm{C}$, and $95^{\circ} \mathrm{C}$ increased through 4 months of curing. After 6 months of curing at $75^{\circ} \mathrm{C}$ and $85^{\circ} \mathrm{C}$, however, the average weight had decreased from the 4 -month values, while the weight of the $95^{\circ} \mathrm{C}$ samples continued to increase.

It is believed that all the weight gains in the samples were due to water absorption into the grouts because of the high salt content and the corresponding high osmotic pressures. The data in Figure 3 indicate that increases in the as-cured bulk density of the grout samples correspond to increases in weight during curing. The correlation of weight change and density is very good $\left(R^{2}=0.96\right)$, supporting the belief that the increases in density can be attributed almost entirely to the increase in weight, and not to significant changes in the original bulk volume of the grout. 
The data in Tables 9 and 10 were used to determine the density of the grout samples corrected for the changes in weight during curing, the bulk dry density, and an estimated volume change during curing. The results of these calculations are shown in Table 11. The corrected densities were calculated from the bulk volumes of the as-cured grout samples and the weights of the grout samples prior to curing.

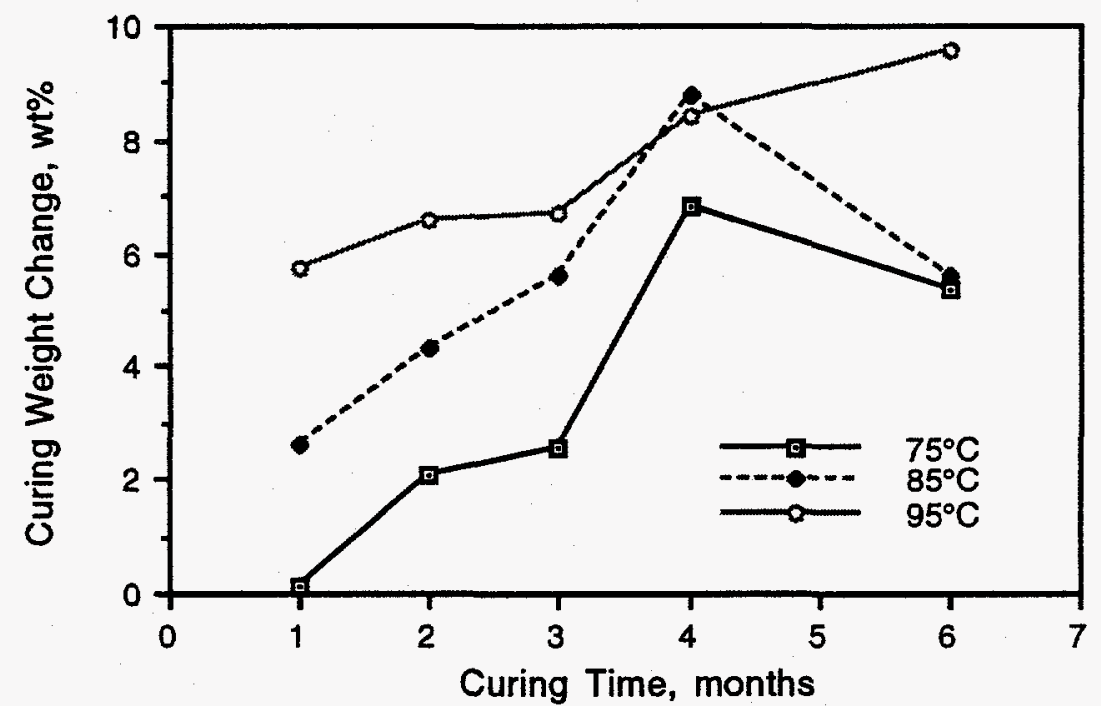

EIGURE 2. Curing Weight Change of DSSF Grouts Cured at $75^{\circ} \mathrm{C}, 85^{\circ} \mathrm{C}$, and $95^{\circ} \mathrm{C}$ 
IABLE 11. Summary of Corrected Density. Dry Density, and Estimated Volume Change During Curing of DSSF Grout Samples

\begin{tabular}{|c|c|c|c|c|c|c|c|c|c|c|}
\hline \multirow{2}{*}{$\begin{array}{l}\text { Curing } \\
\frac{\text { Temp.. }}{75}{ }^{\circ} \mathrm{C}\end{array}$} & \multirow{2}{*}{$\begin{array}{l}\begin{array}{c}\text { Curing } \\
\text { Time }\end{array} \\
1 \\
2 \\
3 \\
4 \\
6\end{array}$} & \multicolumn{3}{|c|}{$\begin{array}{c}\text { Corrected } \\
\text { Density } \\
\mathrm{g} / \mathrm{cm}^{3}\end{array}$} & \multicolumn{3}{|c|}{$\begin{array}{c}\text { Dry Density. } \\
\mathrm{g} / \mathrm{cm}^{3}\end{array}$} & \multicolumn{2}{|c|}{$\begin{array}{c}\text { Estimated } \\
\text { Volume Change, } \\
\text { Vol\% } \\
\end{array}$} & \multirow{2}{*}{$\begin{array}{c}\text { No. of } \\
\text { Samples } \\
3 \\
3 \\
2 \\
3 \\
3\end{array}$} \\
\hline & & $\begin{array}{l}1.663 \\
1.665 \\
1.656 \\
1.660 \\
1.663\end{array}$ & $\begin{array}{l} \pm \\
\pm \\
\pm \\
\pm \\
\pm\end{array}$ & $\begin{array}{l}0.006 \\
0.005 \\
0.004 \\
0.009 \\
0.016\end{array}$ & $\begin{array}{l}1.127 \\
1.170 \\
1.175 \\
1.246 \\
1.220\end{array}$ & $\begin{array}{l} \pm \\
\pm \\
\pm \\
\pm \\
\pm\end{array}$ & $\begin{array}{l}0.015 \\
0.037 \\
0.027 \\
0.013 \\
0.043\end{array}$ & $\begin{array}{r}-0.12 \pm \\
-0.26 \pm \\
0.31 \pm \\
0.03 \pm \\
-0.15 \pm\end{array}$ & $\begin{array}{l}0.35 \\
0.28 \\
0.22 \\
0.54 \\
0.94\end{array}$ & \\
\hline 85 & $\begin{array}{l}1 \\
2 \\
3 \\
4 \\
6\end{array}$ & $\begin{array}{l}1.645 \\
1.654 \\
1.662 \\
1.665 \\
1.676\end{array}$ & $\begin{array}{l} \pm \\
\pm \\
\pm \\
\pm \\
\pm\end{array}$ & $\begin{array}{l}0.007 \\
0.007 \\
0.016 \\
0.003 \\
0.009\end{array}$ & $\begin{array}{l}1.162 \\
1.202 \\
1.231 \\
1.291 \\
1.237\end{array}$ & $\begin{array}{l} \pm \\
\pm \\
\pm \\
\pm \\
\pm\end{array}$ & $\begin{array}{l}0.024 \\
0.046 \\
0.059 \\
0.025 \\
0.052\end{array}$ & $\begin{array}{r}0.99 \pm \\
0.44 \pm \\
-0.03 \pm \\
-0.22 \pm \\
-0.89 \pm\end{array}$ & $\begin{array}{l}0.44 \\
0.43 \\
0.96 \\
0.19 \\
0.54\end{array}$ & $\begin{array}{l}3 \\
3 \\
3 \\
3 \\
3\end{array}$ \\
\hline 95 & $\begin{array}{l}1 \\
2 \\
3 \\
4 \\
6\end{array}$ & $\begin{array}{l}1.661 \\
1.672 \\
1.671 \\
1.662 \\
1.651\end{array}$ & $\begin{array}{l} \pm \\
\pm \\
\pm \\
\pm \\
\pm\end{array}$ & $\begin{array}{l}0.011 \\
0.001 \\
0.003 \\
0.008 \\
0.007\end{array}$ & $\begin{array}{l}1.233 \\
1.242 \\
1.252 \\
1.258 \\
1.264\end{array}$ & $\begin{array}{l} \pm \\
\pm \\
\pm \\
\pm \\
\pm\end{array}$ & $\begin{array}{l}0.071 \\
0.048 \\
0.008 \\
0.008 \\
0.004\end{array}$ & $\begin{array}{l}-0.01 \pm \\
-0.68 \pm \\
-0.57 \pm \\
-0.05 \pm \\
0.60 \pm\end{array}$ & $\begin{array}{l}0.65 \\
0.04 \\
0.21 \\
0.49 \\
0.40\end{array}$ & $\begin{array}{l}2 \\
2 \\
3 \\
3 \\
2\end{array}$ \\
\hline
\end{tabular}

(a) Curing time in months

(b) \pm values represent one standard deviation from average

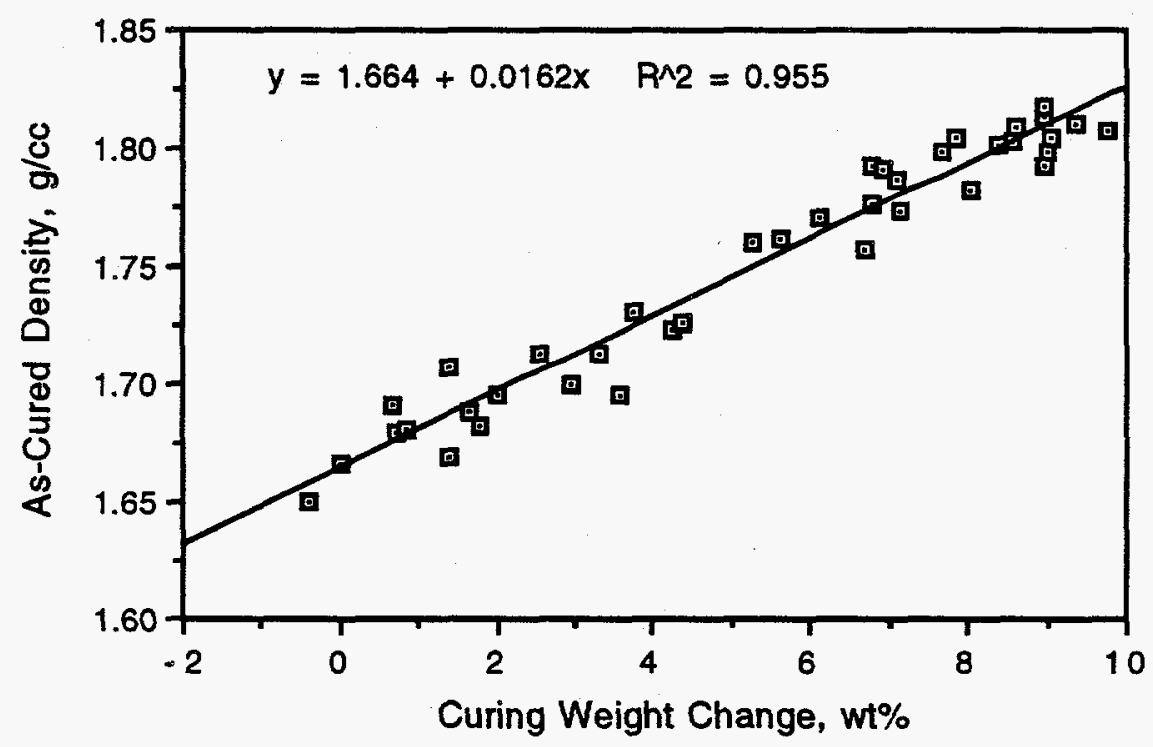

FIGURE 3. As-Cured Density as a Function of Weight Change During Curing for DSSF Grout Samples Cured at $75^{\circ} \mathrm{C}, 85^{\circ} \mathrm{C}$, and $95^{\circ} \mathrm{C}$ for 1 to 6 Months 
Figure 4 illustrates the relationship between corrected density and ascured density for DSSF grout samples cured up to 6 months at temperatures of $75^{\circ} \mathrm{C}, 85^{\circ} \mathrm{C}$, and $95^{\circ} \mathrm{C}$. The regression line for the data suggests that there as-cured density may have a slight effect on the corrected density. Because the corrected densities are based on the initial weight of the grout, a decrease in these values would be caused by an increase in volume. However, the small slope and the poor correlation $\left(R^{2}=0.11\right)$ support the belief that the increase in density of the DSSF grouts during curing was due primarily to weight gain rather than volume changes, as discussed above.

The dry densities listed in Table 11 were calculated from the as-cured bulk volumes and the weights of the grout samples after drying at $105^{\circ} \mathrm{C}$.

These values represent the amount of initial solids present in the grouts and any solid reaction products formed by the hydration reactions. The estimated dry density of DSSF grout slurry prior to any reactions averages $1.118 \pm 0.006$ $\mathrm{g} / \mathrm{cm}^{3}$. This value is based on a slurry density of $1.661 \pm 0.008 \mathrm{~g} / \mathrm{cm}^{3}$ and an initial evaporable water content of 37.2 wt\%. The dry densities of all the samples cured at $75^{\circ} \mathrm{C}$ to $95^{\circ} \mathrm{C}$ increased with curing times up to 4 months, indicating continuing reactions that produced additional solid products. The

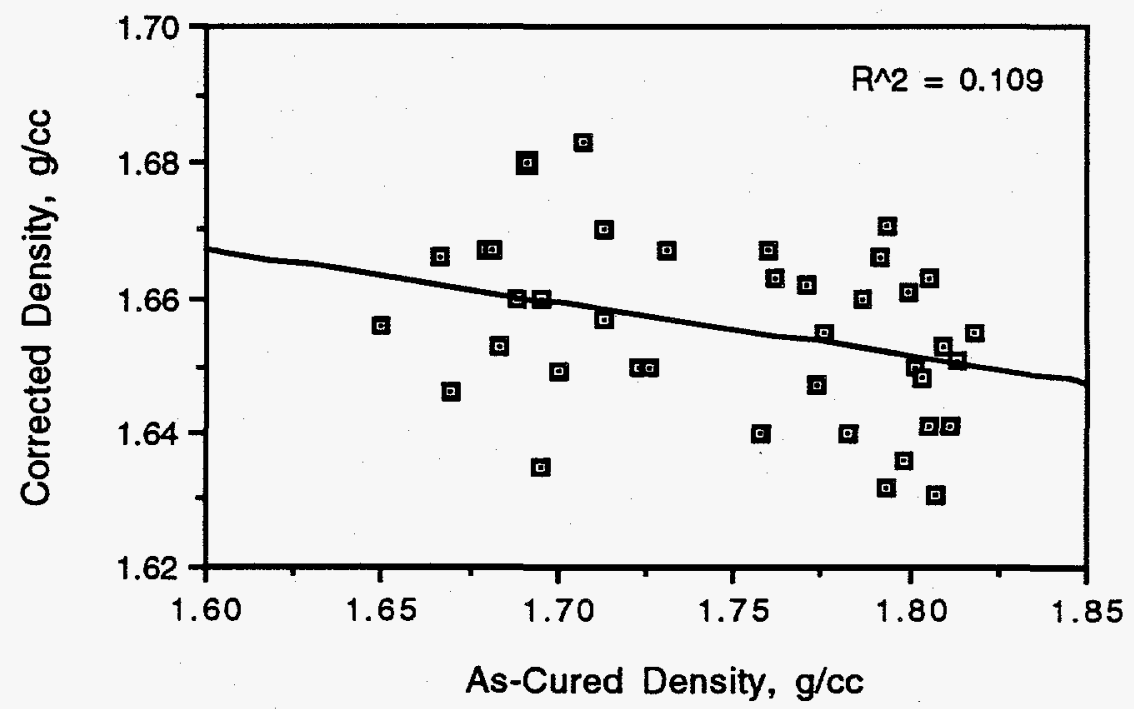

FIGURE 4. As-Cured Density vs. Density Corrected for Curing Weight Change for DSSF Grout Samples Cured at $75^{\circ} \mathrm{C}, 85^{\circ} \mathrm{C}$, and $95^{\circ} \mathrm{C}$ for 1 to 6 Months 
dry densities of the samples cured for 6 months at $75^{\circ} \mathrm{C}$ and $85^{\circ} \mathrm{C}$ decreased slightly relative to the 4 -month densities. These effects are consistent with the weight gained during curing, the amount of evaporable water present after curing, and the estimated amount of water reacted (see Table 10).

The estimated volume changes were determined by the ratios of the corrected densities and the average slurry density (i.e.. $1.661 \mathrm{~g} / \mathrm{cm}^{3}$ ). Although this method of calculating volume change is not exact because the initial volume of the individual samples was not determined, the results suggest that the estimated volume change at curing temperatures of $75^{\circ} \mathrm{C}$ to $95^{\circ} \mathrm{C}$ is typically less than \pm 1 vol\%, with an overall average of -0.05 vol\%.

\section{WATER VAPOR DIFFUSIVITY}

The high curing temperatures $\left(\sim 90^{\circ} \mathrm{C}\right)$ that the DSSF grouts wi11 be exposed to during the first few decades after disposal will result in a driving force for water vapor to diffuse from the grout and into the surroundings. As the grout cools, the water vapor pressures above the saturated salt solution in the grout may provide a gradient to cause water vapor to return to the grout.

A simple test to measure the rates of water vapor transport from DSSF grout samples and subsequent reabsorption into the grout was conducted. In this test, cylindrical samples of DSSF grout cured at $75^{\circ} \mathrm{C}, 85^{\circ} \mathrm{C}$, and $95^{\circ} \mathrm{C}$ were placed in a forced-air convection oven operating at $60^{\circ} \mathrm{C}$ and near $0 \%$ relative humidity. The weights of the samples were monitored with time until constant readings were obtained. Following the drying phase, the samples were placed in a container maintained at $100 \%$ relative humidity at $60^{\circ} \mathrm{C}$. Again, the weights were monitored with time. Figure 5 illustrates the results of these tests. The weight of the samples cured at $75^{\circ} \mathrm{C}$ and $85^{\circ} \mathrm{C}$ decreased at about the same rate, reaching a constant weight after about 9 days. The rate of weight change for the $95^{\circ} \mathrm{C}$ sample showed a continual decrease throughout the drying period. Compared with the rates of weight change for the other samples, the rate of change for the $95^{\circ} \mathrm{C}$ sample was greater at the beginning and gradually became less after the first day. The differences may be due to differences in the pore size distribution between the samples. A large fraction of the evaporable water may have been held in smaller pores in the $95^{\circ} \mathrm{C}$ sample. After the samples were placed in a $100 \%$ relative humidity 
atmosphere, water was absorbed very rapidly, with the samples reaching nearly $100 \%$ saturation within about 2 days. The large difference between the rates of water loss and water gain is caused by osmotic pressures and capillary forces within the grouts.

\section{LEACHABILITY}

ANS 16.1 leach tests were conducted on DSSF grout samples cured at $75^{\circ} \mathrm{C}$, $85^{\circ} \mathrm{C}$, and $95^{\circ} \mathrm{C}$ for 1,3 , and 6 months. These tests were conducted to determine relative changes in the leach behavior of DSSF grout as a function of curing time and curing temperature, rather than to provide direct data for assessing the performance of the grout disposal system. Also, changes in the leaching behavior can provide insight into physical and chemical changes that may be occurring within the grout. The grout samples were leached for 91 days in deionized water. The leachates were analyzed by ICP for cations, IC for anions, and for TOC and $\mathrm{pH}$. Only the analytical data for $\mathrm{Al}, \mathrm{Ca}, \mathrm{Na}, \mathrm{Si}, \mathrm{NO}_{3}$, and TOC were used for evaluating the effective diffusivities. Aluminum, Ca, and $\mathrm{Si}$ were included because they comprise the majority of the solid phases. Nitrate. Na, and TOC were analyzed because they were expected to remain mostiy within the liquid phase in the grout, where their release would be controlled

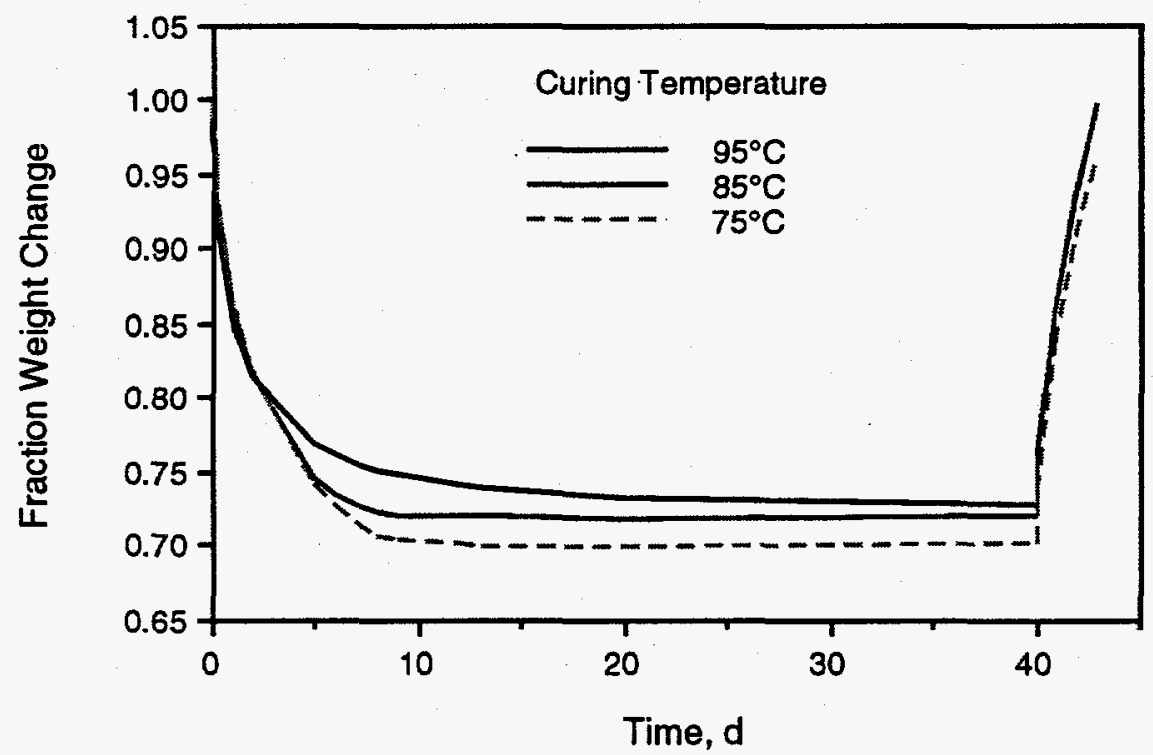

FIGURE 5. Water Vapor Diffusion Out of and Into DSSF Grout Samples at $60^{\circ} \mathrm{C}$. Samples were Cured at $75^{\circ} \mathrm{C}, 85^{\circ} \mathrm{C}$, and $95^{\circ} \mathrm{C}$ for 1 Month 
by diffusion.

In the calculation of effective diffusion coefficients, the original inventory of species present in the grout samples $\left(A_{0}\right)$ was calculated from analytical data for the starting waste and the dry blend constituents, and was assumed to be the same for all samples. The following discussion focuses primarily on $\mathrm{NO}_{3}$ and $\mathrm{Na}$ release from the grout samples, and on the $\mathrm{pH}$ of the resultant leachates. Table 12 summarizes the leachability indices for $\mathrm{Na}$ and $\mathrm{NO}_{3}$ for the DSSF grout samples.

Figures 6 through 8 illustrate the effect of curing temperature and curing time on the cumulative fraction of $\mathrm{NO}_{3}$ leached from DSSF grout samples. As shown in Figure 6 , the amount of $\mathrm{NO}_{3}$ leached from the sample cured for 6 months at $75^{\circ} \mathrm{C}$ is more than 4 times greater than the amount leached from the sample cured for 1 month. The curve for the amount of $\mathrm{NO}_{3}$ leached from the sample cured for 3 months lies between the other two curves, showing the dependence of curing time on the leachability of $\mathrm{NO}_{3}$ from these samples.

The effect of curing time on the $\mathrm{NO}_{3}$ leachability for the samples cured at $95^{\circ} \mathrm{C}$ is shown in Figure 7 . There is no significant effect from curing longer than 3 months on the amount of $\mathrm{NO}_{3}$ leached from these samples. The rate of release for the 3-month and 6-month samples is extremely high, with almost total depletion of $\mathrm{NO}_{3}$ within 5 days of leaching. The initial rate of $\mathrm{NO}_{3}$ release from the sample cured for 1 month is smaller than the release rate for the other samples; however, after about 5 days, the rates are similar, as

IABLE 12. Average $\mathrm{Na}$ and $\mathrm{NO}_{3}$ Leachability Indices for DSSF Grout Samples Leached by the ANS 16.1 Procedure

\begin{tabular}{|c|c|c|c|}
\hline $\begin{array}{l}\text { Curing } \\
\text { Temp.. }{ }^{\circ} \mathrm{C}\end{array}$ & $\begin{array}{l}\text { Curing } \\
\text { Time, months }\end{array}$ & $L_{N a}$ & $\mathrm{LNO}_{3}$ \\
\hline 75 & $\begin{array}{l}1 \\
3 \\
6\end{array}$ & $\begin{array}{l}8.3 \pm 0.2 \\
7.6 \pm 0.2 \\
7.0 \pm 0.2\end{array}$ & $\begin{array}{l}8.2 \pm 0.1 \\
7.4 \pm 0.2 \\
6.5 \pm 0.2\end{array}$ \\
\hline 85 & $\begin{array}{l}1 \\
3 \\
6\end{array}$ & $\begin{array}{l}7.5 \pm 0.2 \\
6.9 \pm 0.4 \\
6.2 \pm 0.5\end{array}$ & $\begin{array}{l}7.4 \pm 0.2 \\
6.5 \pm 0.4 \\
5.7 \pm 0.5\end{array}$ \\
\hline 95 & $\begin{array}{l}1 \\
3 \\
6\end{array}$ & $\begin{array}{l}6.8 \pm 0.4 \\
6.0 \pm 0.5 \\
5.9 \pm 0.5\end{array}$ & $\begin{array}{l}6.4 \pm 0.4 \\
5.9 \pm 0.5 \\
5.7 \pm 0.5\end{array}$ \\
\hline
\end{tabular}


evidenced by the slope of the curves.

Comparing the curves in Figures 6 and 7 shows that the $\mathrm{NO}_{3}$ release from the sample cured for 6 months at $75^{\circ} \mathrm{C}$ is nearly the same as the release from the sample cured for 1 month at $95^{\circ} \mathrm{C}$. Comparing the data in Tables 9 through 11 shows that other properties of the samples cured under these conditions are also very similar. These similarities suggest that whatever caused the leach resistance of the grout to decrease may be kinetically controlled.

Figures 8 and 9 illustrate the changes in leachate $\mathrm{pH}$ during the ANS 16.1 leach test. As shown in the figures, there was a large range of pH values depending on the curing temperature of the grout samples. The overall values of $\mathrm{pH}$ tend to parallel the amount of $\mathrm{NO}_{3}$ leached from the samples, i.e., higher $\mathrm{pH}$ values correspond to larger amounts of $\mathrm{NO}_{3}$ leached. The $\mathrm{pH}$ values of the leachates for the samples cured for 6 months were higher than those for the samples cured for 1 month. The amount of $\mathrm{NO}_{3}$ leached was also greater from the samples cured for 6 months.

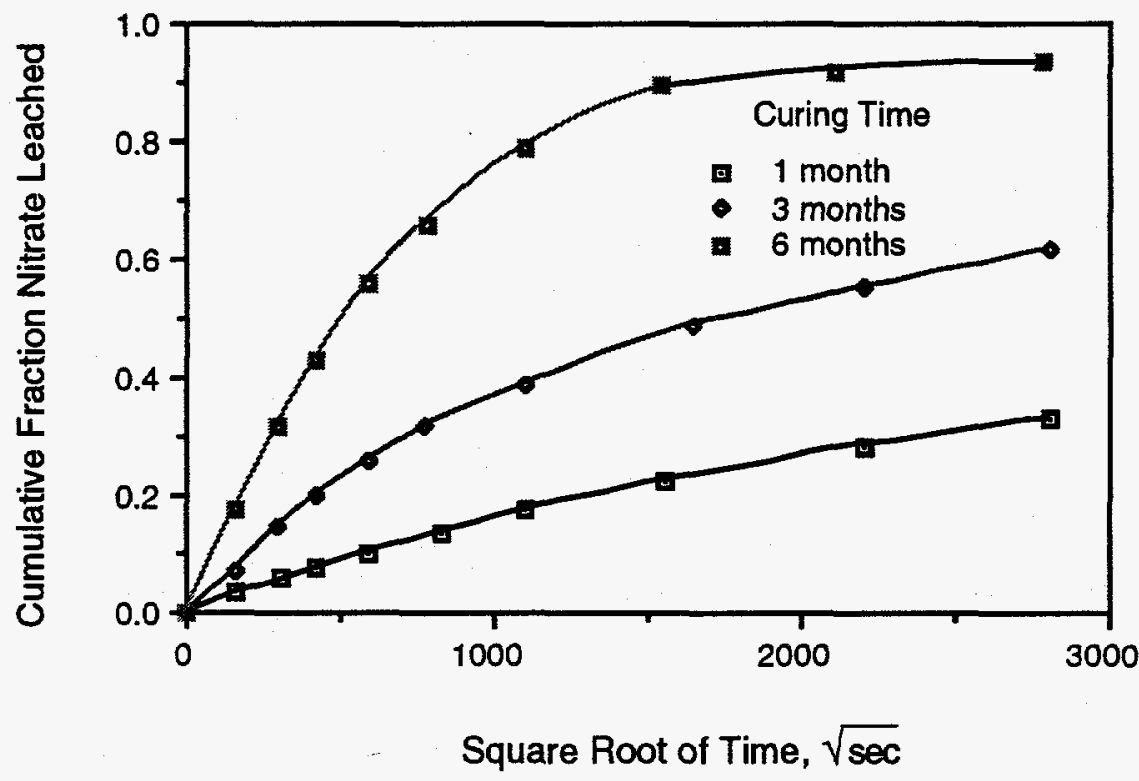

EIGURE 6. Cumulative Fraction of Nitrate Leached from DSSF Grout Samples Cured at $75^{\circ} \mathrm{C}$ for 1,3 , and 6 Months 


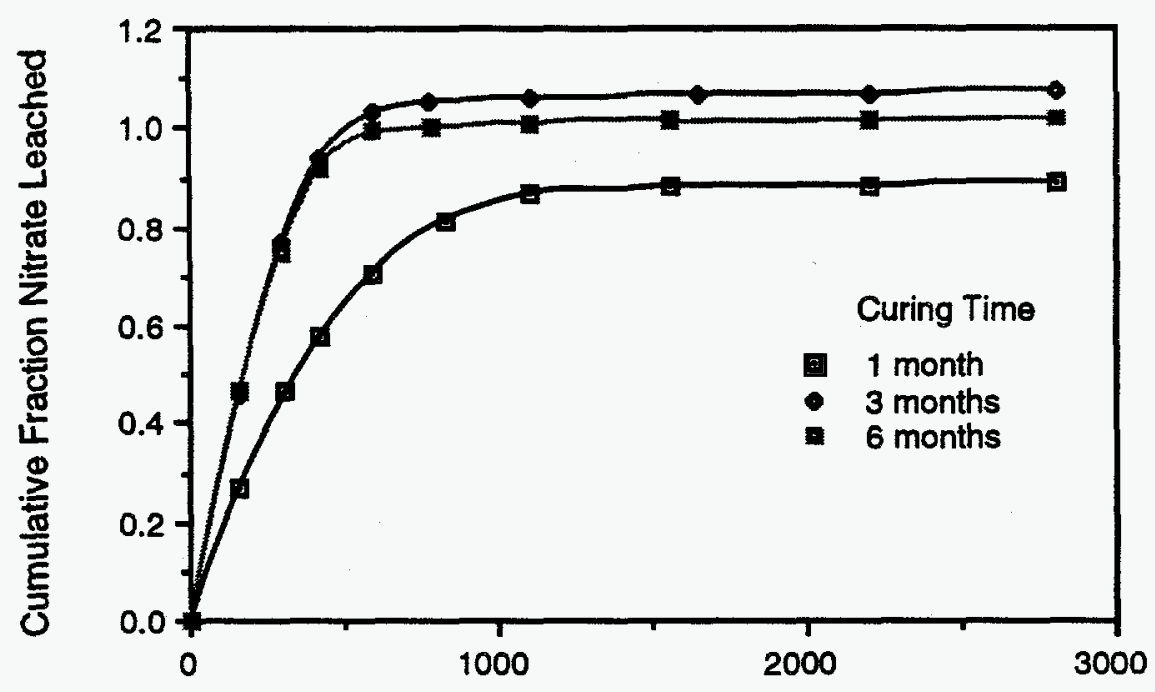

Square Root of Time, $\sqrt{\sec }$

FIGURE 7. Cumulative Fraction of Nitrate Leached from DSSF Grout Samples Cured at $95^{\circ} \mathrm{C}$ for 1,3 , and 6 Months

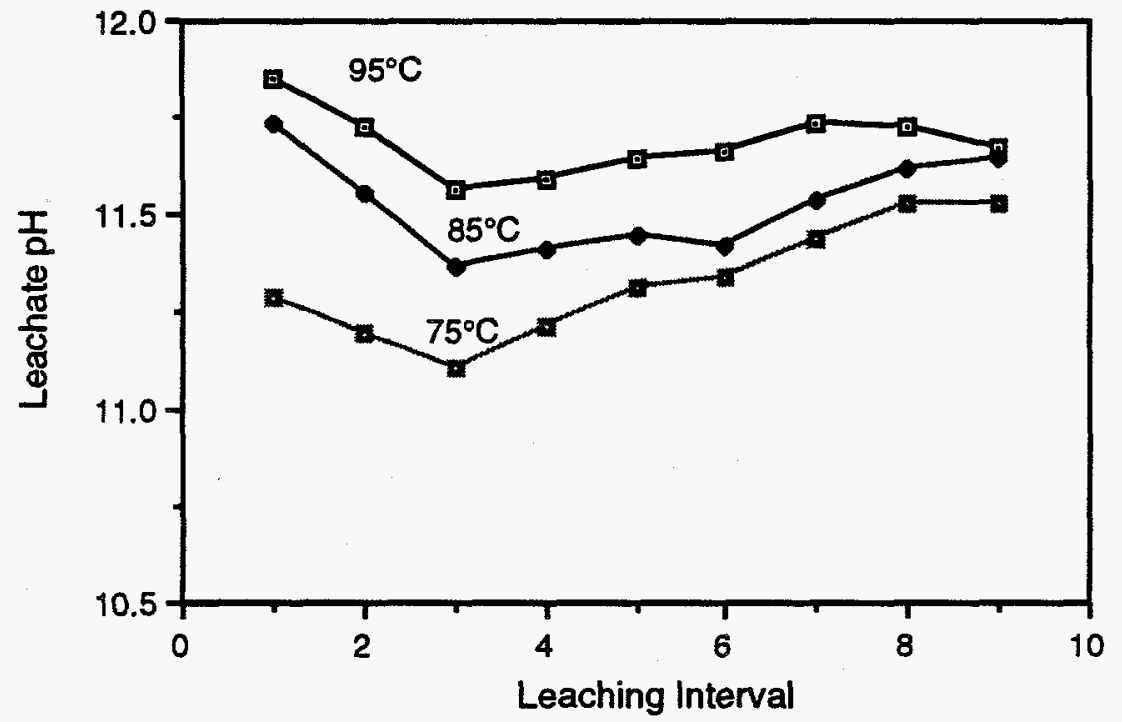

FIGURE 8. Leachate pH from ANS 16.1 Leach Tests on DSSF Grout Samples Cured for 1 Month at $75^{\circ} \mathrm{C}, 85^{\circ} \mathrm{C}$, and $95^{\circ} \mathrm{C}$ 


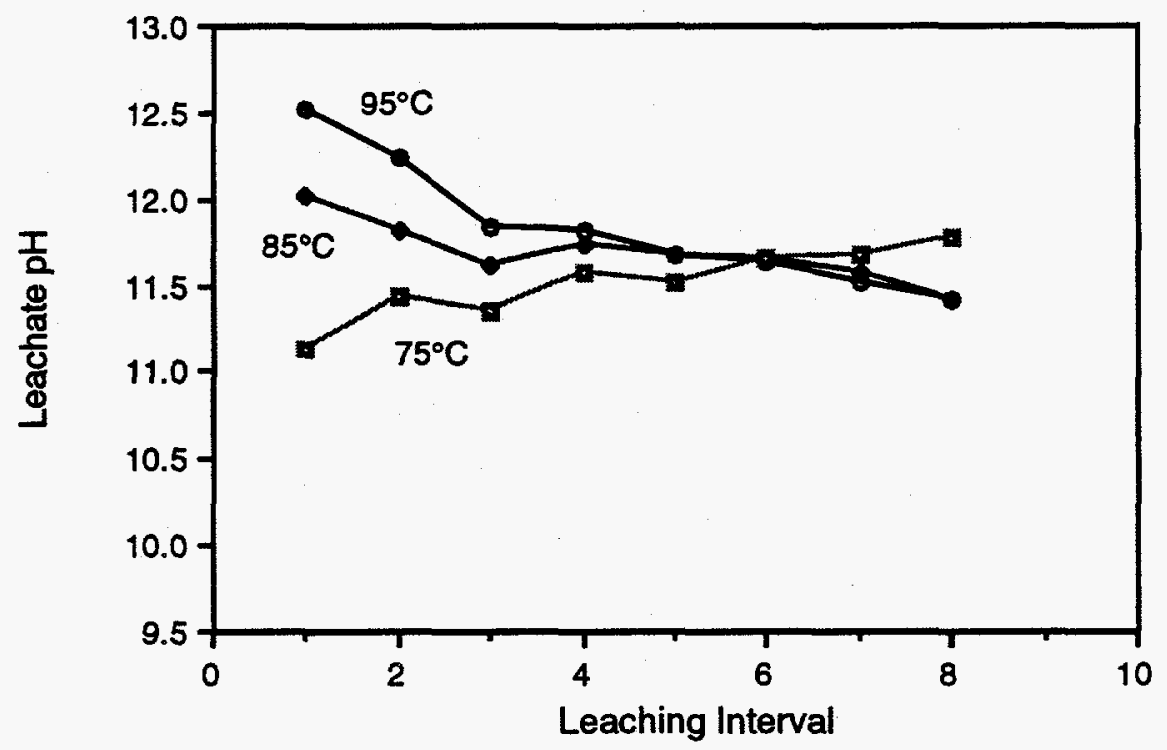

FIGURE 9. Leachate $\mathrm{pH}$ from ANS 16.1 Leach Tests on DSSF Grout Samples Cured for 6 Months at $75^{\circ} \mathrm{C}, 85^{\circ} \mathrm{C}$, and $95^{\circ} \mathrm{C}$

Figures 10 and 11 summarize the effects of curing time and curing temperature on the leachability indices for $\mathrm{Na}$ and $\mathrm{NO}_{3}$, respectively. As shown in the figures, both curing time and curing temperature have a large influence on the leachability indices for both $\mathrm{Na}$ and $\mathrm{NO}_{3}$. The effect of curing temperature is greatest at the shorter curing times, and the effect of curing time is greatest at the lower curing temperatures. Comparing the curves in Figure 11 shows that curing for 6 months at $75^{\circ} \mathrm{C}$ results in a leachability index that is equivalent to curing for 3 months at $85^{\circ} \mathrm{C}$, or 1 month at $95^{\circ} \mathrm{C}$. The large effect of time and temperature on the leach resistance appears to be related to the physical changes that occurred in the grout samples during curing, predominantly densification of hydrated phases. As discussed above, microcracking also may have occurred either during curing as a result of water absorption, or during cooling as a result of salt crystallization. If the extent of microcracking were severe, the effective surface area available for leaching under saturated conditions could have increased significantly. 


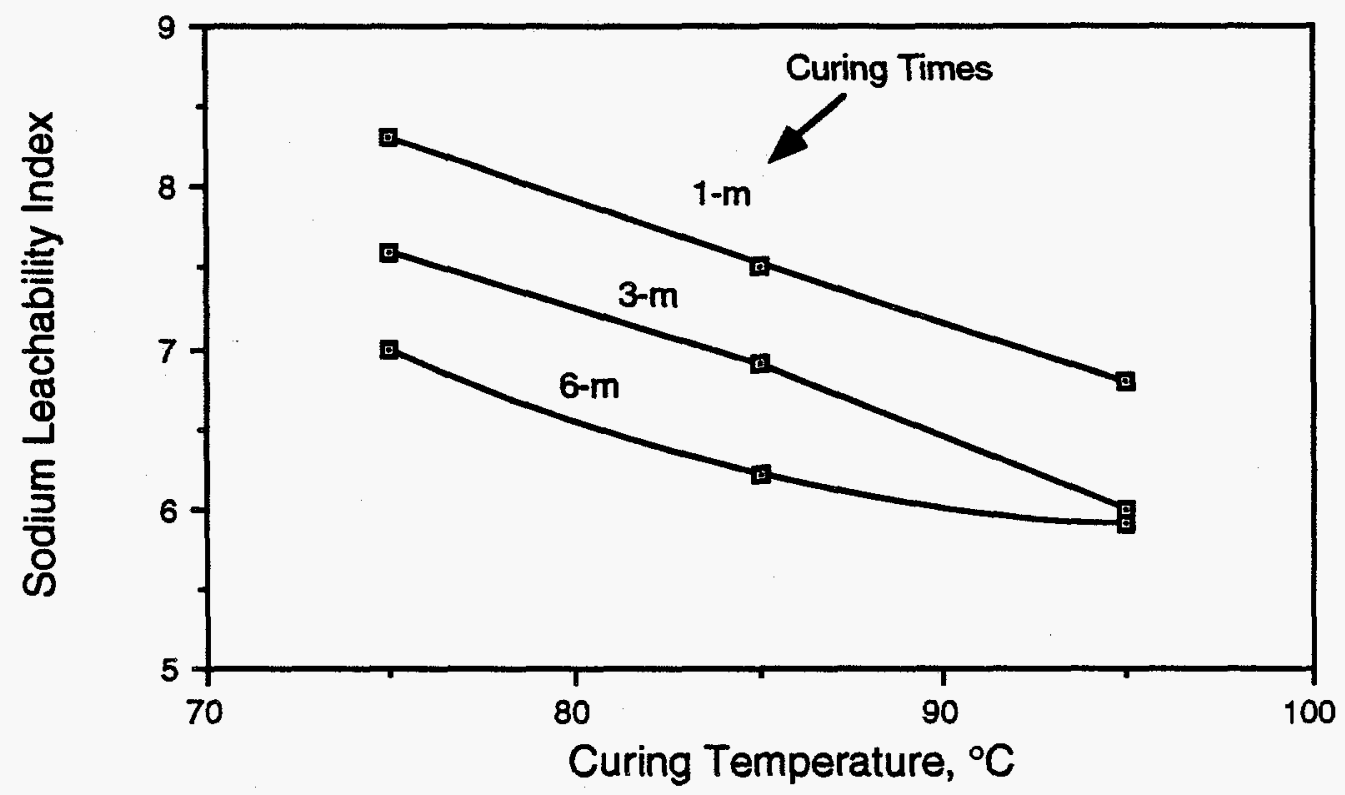

EIGURE 10. Sodium Leachability Index for DSSF Grouts as a Function of Curing Temperature and Curing Time

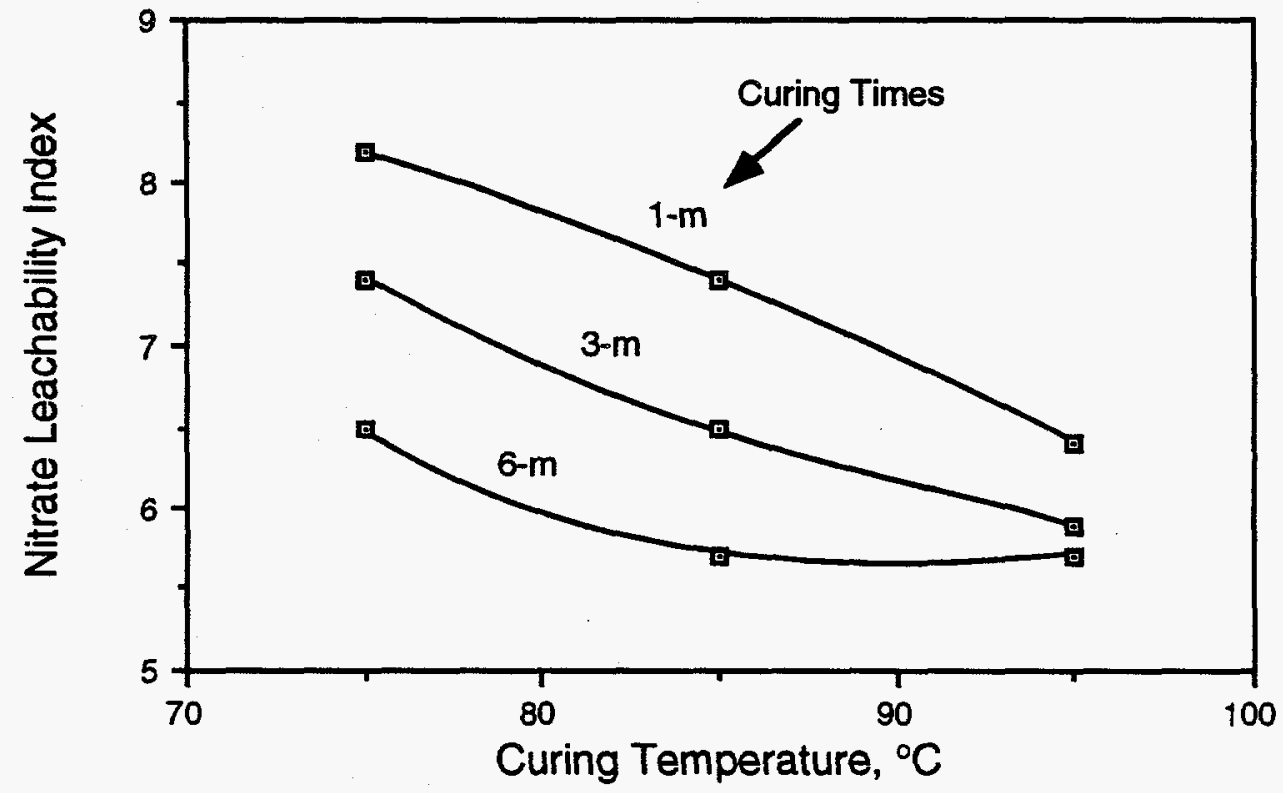

FIGURE 11. Nitrate Leachability Index for DSSF Grouts as a Function of Curing Temperature and Curing Time 


\section{DSSF GROUT CHEMISTRY}

A series of tests were conducted on DSSF grout samples to investigate the cause of the significant, negative effects of increased curing temperature and curing time on the leaching behavior. As discussed above, the interpretations of the leach test results were based on the assumption that a 11 of the cured grout samples were of the same initial composition - i.e., the overall bulk composition did not change during curing.

In the first test, the amount of soluble species in DSSF grout samples cured for 1 month was determined. The samples were first dried at $105^{\circ} \mathrm{C}$. The dried grouts were then pulverized in a laboratory grinding mi11. Two grams of powder were leached for 48 hours in $1 \mathrm{~L}$ of distilled water. The resultant solutions were filtered and analyzed by ICP and IC. The results of these analyses are presented in Table 13. The concentration of species in the solutions of grouts did not appear to be greatly influenced by curing temperature. The $\mathrm{Ca}$ concentration decreased slightly with increased curing temperature; however, the concentrations of the other species were about the same for all the samples.

Samples of dried DSSF grout powder were submitted for ICP analys is to determine the total amount of species in the samples. The results, shown in Table 14, were normalized with respect to the calculated, original Ca concentration to allow a better comparison of the ratios of the other species. only the cationic species were determined because the analytical methods involved fusion of the powders followed by acid dissolution, which volatilizes most anions. The normalized concentration of most of the species is the same in all the samples, indicating that the bulk composition of the samples did not change appreciably during curing.

Several DSSF grout samples that had been cured up to 6 months were used to determine the composition of pore solution contained in the grouts.

Cylindrical samples were first placed in a container at $100 \%$ relative humidity and allowed to come to equilibrium (i.e.. constant weight). The samples were then placed in a steel die and a pressure of approximately 10,000 psi was applied for about 15 minutes. The solution that was extracted was collected in a syringe. The solution was filtered and the filtrate was submitted for ICP 
and IC analyses. Table 15 shows the results of these analyses. Some general trends are shown by the data. For example, in most cases, the $\mathrm{Na}$ concentration in the pore solutions increased with 1) increased curing time at a given temperature, and 2) increased curing temperature for a specific curing time. The $\mathrm{NO}_{3}$ concentration in the samples cured for 1 month also increased with increased curing temperature: however, in the 6-month samples, there was very little difference in the $\mathrm{NO}_{3}$ concentrations.

IABLE 13. Concentration of Solutions Prepared with $2 \mathrm{~g}$ of Dried DSSF Grout Powders in $1 \mathrm{~L}$ of Deionized Water

\begin{tabular}{|c|c|c|c|c|c|c|c|c|c|}
\hline \multirow{2}{*}{$\begin{array}{c}\text { Cure } \\
\text { Temperature }\end{array}$} & \multicolumn{8}{|c|}{ Amount in Solution, $\mathrm{mg} / \mathrm{L}$} & \multirow[b]{2}{*}{$\mathrm{pH}$} \\
\hline & A1 & $\mathrm{Ca}$ & k & $\mathrm{Na}$ & $\mathrm{Cl}$ & $\mathrm{NO}_{2}$ & $\mathrm{NO}_{3}$ & $\mathrm{SO}_{4}$ & \\
\hline $75^{\circ} \mathrm{C}$ & 2.41 & 11.0 & 11 & 97 & 5.6 & 19.6 & 166 & 25 & 11.10 \\
\hline $85^{\circ} \mathrm{C}$ & 2.56 & 7.2 & 14 & 112 & 5.7 & 19.2 & 180 & 29 & 11.06 \\
\hline $95^{\circ} \mathrm{C}$ & 1.63 & 4.6 & 13 & 104 & 4.7 & 16.6 & 169 & 25 & 10.96 \\
\hline
\end{tabular}


TABLE 14. Composition of Dried DSSF Grout Powders. Analyses were Conducted by ICP.

\begin{tabular}{|c|c|c|c|}
\hline \multirow[b]{2}{*}{ Species } & \multicolumn{3}{|c|}{$\begin{array}{l}\text { Concentration of Solids, wt\% } \\
\text { (Normalized Relative to Ca) }\end{array}$} \\
\hline & $75^{\circ} \mathrm{C}$ & $85^{\circ} \mathrm{C}$ & $95^{\circ} \mathrm{C}$ \\
\hline $\begin{array}{l}\mathrm{Al} \\
\mathrm{B} \\
\mathrm{Ba} \\
\mathrm{Ca} \\
\mathrm{Cr} \\
\mathrm{Fe} \\
\mathrm{K} \\
\mathrm{Mg} \\
\mathrm{Mn} \\
\mathrm{Na} \\
\mathrm{P} \\
\mathrm{Si} \\
\mathrm{Sr} \\
\mathrm{Ti} \\
\mathrm{V} \\
\mathrm{Zn} \\
\mathrm{Zr}\end{array}$ & $\begin{array}{l}5.18 \\
0.047 \\
0.074 \\
9.17 \\
0.054 \\
1.12 \\
0.625 \\
1.14 \\
0.199 \\
6.33 \\
0.167 \\
8.61 \\
0.076 \\
0.687 \\
0.014 \\
0.11 \\
0.035\end{array}$ & $\begin{array}{l}5.15 \\
0.048 \\
0.074 \\
9.17 \\
0.054 \\
1.13 \\
0.794 \\
1.1 \\
0.196 \\
6.9 \\
0.188 \\
8.52 \\
0.077 \\
0.679 \\
0.014 \\
0.109 \\
0.029\end{array}$ & $\begin{array}{l}5.07 \\
0.042 \\
0.073 \\
9.17 \\
0.054 \\
1.13 \\
0.716 \\
1.12 \\
0.195 \\
7.45 \\
0.158 \\
8.38 \\
0.078 \\
0.687 \\
0.014 \\
0.738 \\
0.022\end{array}$ \\
\hline Total & 33.63 & 34.22 & 35.09 \\
\hline
\end{tabular}

TABLE 15. Pore Solution Concentration for DSSF Grouts Cured at $75^{\circ} \mathrm{C}, 85^{\circ} \mathrm{C}$, and $95^{\circ} \mathrm{C}$ for 1 to 6 Months

Pore Solution Concentration, $\mathrm{mg} / \mathrm{L}$

\begin{tabular}{|c|c|c|c|c|c|c|c|c|c|}
\hline Specie & $75-1$ & $75-3$ & $75-6$ & $85-1$ & $85-3$ & $85-6$ & $95-1$ & $95-3$ & $95-6$ \\
\hline A1 & 44.5 & 72 & 43 & 34 & 25 & 28.5 & 71 & 27.5 & 26.5 \\
\hline B & 65.5 & 84 & 163.5 & 50 & 187 & 314 & 153.5 & 289 & 243 \\
\hline $\mathrm{Ca}$ & 326 & 306.5 & 176 & 329 & 231 & 192 & 283.5 & 153.5 & 142.5 \\
\hline $\mathrm{Fe}$ & 5.15 & 6.65 & 7.35 & 5.35 & 8.7 & 2.65 & 8.85 & 2.7 & 4.55 \\
\hline$k$ & 10,400 & 11.550 & 11.850 & 10,900 & 14,350 & 14.350 & 13,200 & 12,750 & 12,800 \\
\hline Mo & 46 & 36 & 21.55 & 43 & 37.5 & 31 & 41 & 25 & 21.7 \\
\hline $\mathrm{Na}$ & 82,800 & 82.500 & 116,950 & 86.050 & 108.250 & 120,400 & 99.150 & 118.350 & 127.050 \\
\hline Si & 14 & 26 & 228 & 11.2 & 90.5 & 189 & 79.5 & 218.5 & 250 \\
\hline $\mathrm{Cl}$ & 5,200 & 5,800 & 4,515 & 5,760 & 6,310 & 5.345 & 6,130 & 5,150 & 4.800 \\
\hline $\mathrm{NO}_{2}$ & 22.900 & 20,700 & 25,950 & 20,500 & 27.900 & 26,950 & 24,650 & 28,650 & 27,700 \\
\hline $\mathrm{NO}_{3}$ & 175,550 & 188,100 & 194,200 & 185.050 & 226.700 & 211,250 & 202,100 & 220,250 & 210.750 \\
\hline $\mathrm{SO}_{4}$ & 17,300 & 19,400 & 21.100 & 18.000 & 26,200 & 24,450 & 23.700 & 24.000 & 22,550 \\
\hline Total & 315 & 329 & 375 & 327 & 410 & 404 & 370 & 410 & 406 \\
\hline
\end{tabular}





\section{REFERENCES}

American Nuclear Society (ANS). 1986. Measurement of the Leachability of Solidified Low-Level Radioactive Wastes by a Short-Term Test Procedure. ANSI/ANS 16.1-1986. American Nuclear Society. LaGrange Park. Illinois.

Claghorn, R. D. 1987. Compositional Limits for Grout Feed: Double-Shell Slurry and Retrieved Double-Shell Slurry Formulation Experiments. RHO-RE-EV96. Rockwell Hanford Operations, Richland, Washington.

Lea, F. M. 1971. The Chemistry of Cement and Concrete. Third Edition. Chemical Publishing Company. Inc., New York. New York.

Lokken, R. O., P. F. C. Martin, and J. W. Shade. 1992. Characterization of a Double-Shell Slurry Feed Grout Produced in a Pilot-Scale Test. PNL-7979. Pacific Northwest Laboratory, Richland. Washington.

Neville, A. M. 1981. Properties of Concrete. Third Edition. Pitman

Publishing Inc.. Marshfield, Massachusetts.

Regourd. M., J. H. Thomassin, P. Baillif and J. C. Touray. 1983. "BlastFurnace Slag Hydration. Surface Analysis," Cement and Concrete Research $13(4): 549-556$.

Wu, X., D. M. Roy and C. A. Langton. 1983. "Early Stage Hydration of SlagCement," Cement and Concrete Research 13(2):277-286. 


\section{DISTRIBUTION}

No. of

Copies

OFESITE

2 DOE/Office of Scientific and Technical Information

2 Westinghouse Savannah River Company

Savannah River Site

Aiken, SC 29808-0001

ATTN: C. A. Langton

M. Hay

2 Oak Ridge National Laboratory

P.O. BoX X

Oak Ridge. TN 37831

ATTN: E. W. MCDaniel

R. D. Spence
No. of

Copies

29 Pacific Northwest Laboratory

L. M. Bagassen

K. A. Borgeson

R. E. Einziger

D. K. Kried

R. 0. Lokken (5)

P. F. C. Martin

J. L. MCElroy

G. L. McVay

R. K. Quinn

P. A. Scott

R. J. Serne

P. Sliva

J. H. Westsik, Jr. (5)

G. A. Whyatt

K. D. Wiemers

Publishing Coordination

Technical Report Files (5)

\section{ONSITE}

3

DOE Richland Field office

K. W. Bracken

G. H. Sanders

L. A. Huffman

19 Westinghouse Hanford Company

K. W. Bledsoe

J. M. Connor

J. L. Epstein

A. P. Hammitt

D. W. Hendrickson

A. A. Kruger

D. J. Newl and

W. J. Powell

T. V. Rebagay

E. F. Riebling

J. L. Scott

J. W. Shade

J. E. Van Beek

J. A. Voogd (4)

T. L. Welsh

G. F. Williamson 